\title{
Cost and Energy \\ Consumption Estimates for the Aluminum-Air Battery Anode Fuel Cycle
}

K. K. Humphreys

D. R. Brown

January 1990

Prepared for the U.S. Department of Energy under Contract DE-AC06-76RLO 1830

Pacific Northwest Laboratory Operated for the U.S. Department of Energy by Battelle Memorial Institute 


\title{
DISCLAIMER
}

This report was prepared as an account of work sponsored by an agency of the United States Government. Neither the United States Government nor any agency thereof, nor Battelle Memorial Institute, nor any of their employees, makes any warranty, expressed or implied, or assumes any legal Itability or responsibility for the accuracy, completeness, or usefulness of any information, apparatus, product, or process disclosed, or represents that its use would not infringe privately owned rights. Reference herein to any specific commercial product, process, or service by trade name, trademark, manufacturer, or otherwise, does not necessarily constitute or imply its endorsement, recommendation, or favoring by the United States Government of any agency thereof, or Battelle Memorial Institute. The views and opinions of authors expressed herein do not necessarily state or reflect those of the United States Government or any agency thereof.

\author{
PACIFIC NORTHWEST LABORATORY \\ operated by \\ BATTELLE MEMORIAL, INSTITUTE \\ for the \\ UNITED STATES DEPARTMENT OF ENERGY \\ under Contract DE-ACO6-76RLO 1830
}

Printed in the United States of America

Available to DOE and DOE contractors from the

Office of Scientific and Technical Information, P.O. Box 62, Oak Ridge, TN 37831; prices available from (615) 576-8401. FTS 626-8401.

Available to the public from the National Technical Information Service, U.S. Department of Commerce, 5285 Port Royal Rd., Springfield, VA 22161.

NTIS Price Codes, Microfiche A01

Printed Copy

\begin{tabular}{ccccc}
\hline Price Code & Page Range & & Price Code & Page Range \\
\cline { 4 - 4 } A02 & $1-10$ & & A15 & $326-350$ \\
A03 & $11-50$ & A16 & $351-375$ \\
A04 & $51-75$ & A17 & $376-400$ \\
A05 & $76-100$ & A18 & $401-425$ \\
A06 & $101-125$ & A19 & $426-450$ \\
A07 & $126-150$ & A20 & $451-475$ \\
A08 & $151-175$ & A21 & $476-500$ \\
A09 & $176-200$ & A22 & $501-525$ \\
A10 & $201-225$ & A23 & $526-550$ \\
A11 & $226-250$ & A24 & $551-575$ \\
A12 & $251-275$ & A25 & $576-600$ \\
A13 & $276-300$ & A99 & $601-U p$ \\
A14 & $301-325$ & &
\end{tabular}


COST AND ENERGY CONSUNPTION ESTIMATES FOR THE ALUMINUMAIR BATTERY ANODE FUEL CYCLE

K. K. Humphreys

0 . R. Brown

January 1990

Prepared for the U.S. Department of Energy under Contract DE-ACO6-76RLO 1830

Pacific Northwest Laboratory Richland, Washington 99352 


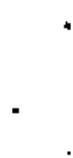




\section{SUMMARY}

At the request of DOE's Office of Energy Storage and Distribution (OESD), Pacific Northwest Laboratory (PNL) conducted a study to generate estimates of the energy use and costs associated with the aluminum anode fuel cycle of the aluminum-air (Al-air) battery. The results of this analysis indisate that the cost and energy consumption characteristics of the mechanically rechargeable Al-air battery system are not as attractive as some other elec:rically rechargeable electric vehicle battery systems being developed by OESD. However, there are distinct advantages to mechanicaliy rechargeable batteries, which may make the Al-air battery (or other mechanically rechargeable batteries) attractive for other uses, such as stand-alone applications. Fuel cells, such as the proton exchange membrane (PEM), and advanced secondary batteries may be better suited to electric vehicle applications. The overall conclusion that Al-air may not be the best technology for providing electric vehicle power is based on a number of findings:

- The expected utility grid-to-shaft efficiency of the Al-air battery is $24 \%$, while grid-to-shaft efficiencies of typical secondary battery systems are approximately $50 \%$.

- A significant breakthrough in A7-air battery technology and improvements in aluminum production processes must occur for the grid-to-shaft efficiency of the Al-air battery to exceed 35 percent.

- Using the Al-air battery in a hybrid vehicle dramatically increases net vehicle efficiency; however, this is due to use of a more efficient secondary battery for most of the supplied power.

- The cost associated with the use of $99.99 \%$ pure aluminum-alloy anodes in the a]uminum-air battery is estimated to be $\$ 2.11$ to $\$ 3.05$ per kilogram of anode consumed. Currently, $99.999 \%$ pure aluminum base metal is required. If this higher purity metal must be used in a mature battery system, costs would likely be even higher.

- The efficiency-adjusted fuel cost of the AT-air battery is \$0.550.80 per kWh of shaft output, while secondary battery systems have efficiency-adjusted fuel costs of approximately $\$ 0.073$ per kwh of shaft output. 
Other findings of this study include the following:

- In a commercialized market, the recycling of hydrargillite, a precipitate of the battery reaction, into new anodes would almost certainly need to be pursued to maintain stable aluminum and alumina markets and to keep the consumer cost of anodes down.

- The size of hydrargillite particles at discharge from the battery system is not a limiting factor for their use as feedstock in the aluminum production process if the hydrargillite calcining process during recycling is closely controlled.

- During repeated processing of hydrargillite through the fuel cycle, the hydrargillite should not pick up significant amounts of impurities.

- The electrolyte solution entrained with the hydrargillite upon discharge from the battery system could be washed away during hydrargillite reprocessing at negligible additional cost and energy consumption, if the aluminum production process used can tolerate low levels of electrolyte in the recycled hydrargillite. If the aluminum production process is not tolerant, washing could be complex and costly.

- The cost of common alloying agents currently being used in the battery development program is not a prime cost driver in the overall operating cost of the Al-air battery.

Considering all these findings, it was concluded that Al-air battery development and integration should be preceded by the evaluation of these fundamental issues:

- the value of special characteristics, such as rapid refuelability, high specific energy, and long-range capability relative to efficiency and the efficiency-adjusted fuel cost

- the likelihood of major efficiency breakthroughs in the battery system and fuel cycle

- specific applications in which the Al-air battery would be more attractive and justify its development.

If evaluation of these issues indicates poor future viability of the A1air battery system, major research efforts should be directed toward other battery or fuel cell systems, such as the PEM fuel ce11, which have higher potential for beneficial applications. Also, the transfer of information learned in Al-air battery development to other technological applications should be strongly pursued. A technology that would be likely to benefit from such transfer is the zinc-air battery system. 


\section{ACKNOWLEDGMENTS}

In addition to the primary report authors, we would like to acknowledge the technical contributions of PNL staff members Bernie J. Wrona and Jim A. Dirks. We extend our thanks to the following individuals for providing technical advice and information: Marilyn Nicksa, Robert Fenn, and Lawrence Frank a1l of ELTECH Systems Corporation; and Gary Tarcy and Robert A. Rand of Alcoa. In addition, we appreciate the technical review by ELTECH Systems Corporation; Arturo Maimoni of LLL; Elton Cairns, Frank McLarnon, and Kim Kinoshita of LBL; and Robert Swaroop of EPRI. 
.

‘

$a$ 


\section{CONTENTS}

ji i

ACKNOWLEDGMENTS .......................... . . . . . . .

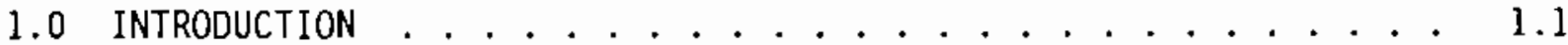

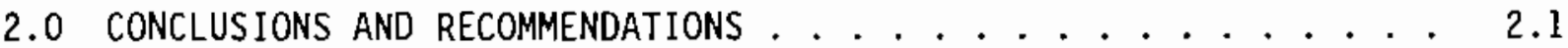

3.0 GENERAL COST AND ENERGY CONSUMPTION ASSESSMENT METHODOLOGY . . . 3.1

4.0 THE SERVICE CYCLE ..................... 4.1

5.0 HYDRARGILLITE REPROCESSING . . . . . . . . . . . . . 5.1

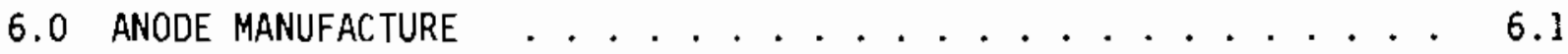

7.0 THE COMPLETE FUEL CYCLE . . . . . . . . . . . . . . . 7.1

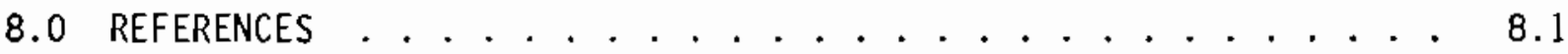

APPENDIX A - ECONOMIC ANALYSIS METHODOLOGY FOR THE DETERMINATION OF HYDRARGILLITE REPROCESSING COSTS . . . . . . . . . A.l

APPENDIX B - CAPITAL AND OPERATING COST ESTIMATES FOR CALCINING AND WASHING/CALCINING FACILITIES FOR HYDRARGILLITE REPROCESSING .................... B.I 


\section{FIGURES}

3.1 Fuel Cycle for the Aluminum-Air Battery . . . . . . . . . . 3.3

5.1 Schematic of the Bayer Process . . . . . . . . . . . . . . . . 5.2

6.1 Hall Process Schematic . . . . . . . . . . . . . . . 6.2 


\section{$\underline{\text { TABLES }}$}

2.1 Comparison of Grid-to-Shaft Efficiencies . . . . . . 2.4

2.2 Range of Anode Cost Estimates . . . . . . . . . . . 2.4

2.3 Comparison of Efficiency-Adjusted Fuel cost . . . . . . . 2.5

4.1 Long-Term Gasoline Taxes Versus Retail cost . . . . . . . . 4.6

5.1 "Best Practice" Energy Inputs to the Bayer Process . . . . . . 5.3

5.2 Direct Energy Consumption of Hydrargillite

Reprocessing Scenarios ............. 5.5

5.3 Capital Investment Cost Estimate for a Calcining Facility

for Hydrargillite Reprocessing . . . . . . . . . 5.6

5.4 Annual Operating Cost Estimate for a Calcining Facility

for Hydrargillite Reprocessing . . . . . . . . . 5.6

5.5 Capital Investment Cost Estimate for a Washing/Calcining Facility

for Hydrargillite Reprocessing . . . . . . . . . . 5.7

5.6 Annual Dperating Cost Estimate for a Washing/Calcining Facility

for Hydrargillite Reprocessing . . . . . . . . . . . 5.7

5.7 Direct Energy Consumption and Cost Estimates for

Reprocessing of Hydrargillite . . . . . . . . . . . . 5.9

6.1 "Best Practice" Energy Inputs to the Ha11 Process . . . . . . 6.3

6.2 Energy Inputs to the Continuous Casting/Shipping Process . . . 6.3

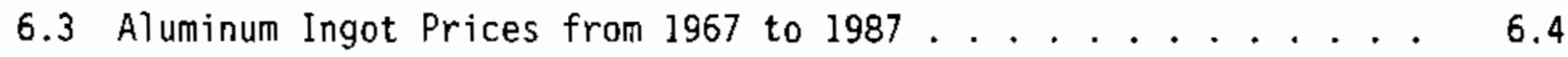

6.4 Anode Cost Estimate . . . . . . . . . . . . . 6.5

7.1 General Fuel Cycle cost Estimates . . . . . . . . . . . 7.3

7.2 Anode Cost Estimate for Alloy with $99.99 \%$ Aluminum Base Metal . . . . . . . . . . . . . . . . . 7.4

7.3 Anode Cost Estimate for $99.5 \%$ Aluminum . . . . . . . . . 7.5

7.4 Range of Anode Cost Estimates . . . . . . . . . . 7.6

A.1 Modified Seven-Year ACRS Depreciation Table for 1987
and Beyond . . . . . . . . . . . . . . . . . . . .

A.2 Discounted and Modified Seven-Year ACRS Depreciation Table for 1987 and Beyond .................... A.3 


\section{TABLES (contd)}

B.l Capital Investment Cost Estimate for a Calcining Facility for Hydrargillite Reprocessing . . . . . . . . . . B.2

B.2 Total Annual Operating Cost for a Calcining Facility for the Reprocessing of Hydrargillite . . . . . . . . . . . B.6

B.3 Capital Investment Cost Estimate for a Washing/Calcining Facility for Hydrargillite Reprocessing . . . . . . . . . . B.8

B.4 Tota1 Annual Operating Cost for a Washing/Calcining Facility for the Reprocessing of Hydrargillite...........

B. 11 


\subsection{INTRODUCTION}

The mechanically rechargeable aluminum-air (A1-air) battery operates as a fuel cell, consuming aluminum alloy piates (anodes) to produce electricity. In addition to electricity, the battery produces hydrated alumina (hydrargillite; as a reaction product. The hydrargillite $\left(\mathrm{Al}_{2} \mathrm{O}_{3} \cdot \mathrm{H}_{2} \mathrm{O}\right)$ is similar to an intermediate product in aluminum production. For this reason, it is believed that the hydrargillite could be recycled into aluminum for reuse as fuel for the battery.

The Al-air battery is seen as potentially viable as a power source for an electric vehicle from a technical standpoint. However, the practicality and economic viability have yet to be proven. The battery is mechanically rechargeable; therefore, an electric vehicle powered by such a battery would be 1 imited in range only by the amount of aluminum fuel the vehicle could carry. This is a significant advantage over secondary-battery-powered electric vehicles, which are range limited by the battery's electrical storage capacity and cannot be rapidiy recharged. An alternative scenario would be to couple a secondary battery with an Al-air battery, utilizing the Al-air portion of the system for meeting peak power requirements and as a range extender.

The net energy consumption and cost of fuel (aluminum plates) of the A7air battery were determined for the process of refining the hydrargillite byproduct into alumina, using the alumina in an aluminum production process to manufacture new aluminum plates and using the plates as battery fuel to produce electricity and hydrargillite. This complete processing loop, from aluminum plate to hydrargillite to alumina and back to aluminum plate, is callec the "fuel cycle" in this study. Because of the relative complexity of the fuel cycle for the Al-air battery-powered vehicle as compared to those powered by secondary batteries, a detailed analys is is required to determine the total cost and direct energy consumption of this fuel cycle. Direct energy is defined as the total energy consumed in 211 manufacturing and reprocessing steps, excluding transportation and embodied energy associated with raw materials. With this information, an informed decision can be made with respect to the cost competitiveness of operating an Al-air battery- 
powered vehicle and the net electrical efficiency of the battery itself, from both a national energy perspective and from a consumer standpoint.

DOE's aluminum-air battery development effort began in the late 1970s; since that time, there have been several studies examining the operating economics and/or energy use of the battery. The first of these efforts was performed in the early 1980s (Hudson and Putnam 1980) and, although it provided a good examination of energy use and operating economics, the preliminary nature of the battery design and operating requirements made it impossible to examine every aspect of the system to the levels of detail currently possible. During the mid-1980s, a number of projects were able to improve the quality of cost and energy-use information. In particular, work performed by McMinn and Branscomb (1981) and Cooper (1984) added significantiy to the information available on aspects of this system. However, as the development of the aluminum-air battery continues and future funding priorities must be established, better-defined, long-term cost estimates and energy use-projections are required to help evaluate the economic feasibility of the battery.

The major objective of this study was to generate estimates of the energy use and costs associated with the aluminum anode fuel cycle of the aluminum-air battery. While this study uses much of the previous work as a foundation, there are three fundamental differences between this work and earlier studies: 1) the energy consumption associated with the aiuminum-air battery-powered vehicle fuel cycle is examined in greater detail than previousiy, 2) the reprocessing cost of the hydrargilitite has been examined to a greater extent than in the past, and 3) the most current baseline operating scenario, which inciudes the addition of $50 \mathrm{~kg}$ of aluminum plates for every three discharges of hydrargillite, additions of water, and possibiy the addition of electrolyte, has been incorporated into the estimates. Additional uncertainty issues have also been identified.

The efficiency analysis methodology used in this study suggests severai important questions that have a critical bearing on the results. First, "Why evaluate electrical efficiency from both national energy and consumer perspectives?" Efficiencies must be evaluated from a national energy 
perspective, because it is DOE's responsibility to promote the development of technologies which will not only succeed in the consumer market place but will also utilize our national energy supplies in the most efficient manner. Efficiency must also be evaluated from a consumer perspective, because this efficiency directly relates to the cost of operations and, consequently, viable commercialization.

Second, "Why use the complex concept of the aluminum anode fuel cycle rather than the simple efficiency measure of roundtrip efficiency (i.e., electrical energy out of the battery divided by electrical energy into the battery)?" For a typical secondary battery (e.g., lead-acid, sodiumsulfur), energy-out divided by energy-in coupled with other system losses is efficiency calculated from a consumer perspective. For an aluminum-air battery which consumes fuel (i.e., aluminum anodes), the consumer only cares about the efficiency with which aluminum is converted to electricity. This parallels the roundtrip efficiency concept of a secondary battery. However from a national energy perspective, a fair evaluation must consider all energy required to make an aluminum-air battery discharge electricity. Because the anodes consumed in the battery require intensive energy input to manufacture them, this energy input, which is a portion of the fuel cycie, must be included in the efficiency analysis.

A final critical question then arises: "If we are going to include the energ: required to manufacture the anodes for an aluminum-air battery, shouldn't the energy required to manufacture lead in lead-acid or sulfur in sodiur-sulfur batteries be included during comparison analysis with the aluminum-air battery?" The answer is no, because every time the aluminumair battery discharges a kWh of electricity, aluminum is consumed. Thus, the alumirum is a consumable commodity. In a conventional secondary battery such as lead-acid, the lead is merely a media for storing energy, and a single pound of lead may last thousands of charges and discharges. Thus, it is not consumed and should not be included in efficiency calculations. 


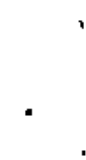




\subsection{CONCLUSIONS AND RECOMMENDATIONS}

Two measures of efficiency and fuel cost for the Al-air battery system were developed in this study. These include grid-to-shaft efficiency and the efficiency-adjusted fuel cost. The grid-to-shaft efficiency is a measure of the energy efficiency of a battery system from a national energy perspective. The efficiency-adjusted fuel cost is the cost of fuel per unit of energy output from the electric vehicle system. These two measurement factors were deternined by analyzing the Al-air battery fuel cycle. Many efficiencies could have been cited, each of which is correct in its own context; however, grid-to-shaft efficiency represents a measure that is comparable for electrically and mechanically recharged batteries. Having a comparable efficiency is significantly more important than the specific type of efficiency measure used.

For estimation purposes, the fuel cycle was divided into three major parts: service cycle aspects, hydrargillite reprocessing, and anode manufacture. Each of these major parts was evaluated with respect to the cost and energy consumption impacts it has on the overall fuel cycle.

The service aspects include four basic operations: installation of the anode:s, removal of hydrargillite, addition of water and electrolyte, and shipment of the hydrargillite to a reprocessing facility. By assessing a number of possible electric vehicle servicing, fuel taxing, and service center profit scenarios, a cost contribution toward the fuel cycle of $\$ 0.36$ 1.30 per kilogram of aluminum is estimated. The only direct energy consumption associated with service aspects of the fuel cycle is shipping the hydrargillite to a reprocessing facility, which requires $529 \mathrm{~kJ}$ per kilogram of aluminum.

Two types of hydrargillite reprocessing operations were evaluated: 1) calcining, and 2) washing and calcining. A significant cost or energy consumption difference between these two alternatives could not be determined. However, aluminum industry experts indicated that washing could be a complex task if the residual electrolyte associated with the hydrargillite is not tolerable by the aluminum production process utilizing the recycled 
hydrargillite. During the evaluation of reprocessing methods, three technical issues were identified and evaluated for their energy consumption and cost implications: 1) how the entrained solution associated with the hydrargillite affects reprocessing; 2) how the particle size of the hydrargillite crystals would affect the use of calcined hydrargillite for producing aluminum; and 3) how repeated cycling of hydrargillite through the fuel cycle affects the amount of impurities, particularly iron, in the aluminum anodes.

It was optimistically concluded that the solution entrained with the hydrargillite could be washed away at the hydrargillite reprocessing facilities at minimal cost and with minimal energy consumption. The particle size problems can also easily be solved. The only requirement of the battery regarding particle size is that the particles must be large enough for the battery separator to collect them. Although the developer's goal of 40 microns for particle size is not large enough for direct use in the Hall process for aluminum production, by carefully controlling calcining temperatures during reprocessing, the particies would agglomerate to the appropriate size. Finally, it was concluded that iron concentrations in the aluminum anodes would remain minimal through repeated fuel cycles. Although some iron would be picked up during the Hall process, an approximately equal amount would volatize from the cell in the form of iron oxides. The estimated cost and energy consumption associated with hydrargillite reprocessing are $\$ 0.084 / \mathrm{kg} \cdot \mathrm{Al}$ and $3550 \mathrm{~kJ} / \mathrm{kg} \cdot \mathrm{Al}$, respectively. The cost reflects credit for the value of recycled hydrargillite.

In a study by Reynolds Aluminum (McMinn and Branscomb 1981), it was concluded that the lowest-cost anodes could be made by going directly from molten Hall cell metal to a continuous anode casting operation. Therefore, this manufacturing approach was used to calculate the energy consumption and cost of anode manufacture. By evaluating the anode manufacturing process at the unit operation level, energy consumption was estimated as $14.51 \mathrm{kWh}$ and $5950 \mathrm{~kJ} / \mathrm{kg} \cdot \mathrm{A} 1$.

The total of all attributed energy consumption for the use of aluminum anodes as fuel for the aluminum-air battery is $10 \times 10^{3} \mathrm{~kJ} / \mathrm{kg} \cdot \mathrm{Al}$ plus 14.5 $\mathrm{kWh} / \mathrm{kg} \cdot \mathrm{Al}$. Using a conversion factor of $10,550 \mathrm{~kJ} / \mathrm{kWh}$, this is equivalent to 
$15.5 \mathrm{kWh} / \mathrm{kg} \cdot \mathrm{Al}$. The aluminum-to-electricity battery efficiency using a BDWseries alloy(a) and calculated over a standard drive cycle was $3.8 \mathrm{kWh} / \mathrm{kg} \cdot \mathrm{Al}$. Based on this efficiency and energy input of $15.5 \mathrm{k} \mathrm{kh} / \mathrm{kg} \cdot \mathrm{Al}$, the net fuel cycle efficiency is $25 \%$.

There is potential for near-term improvement of the fuel cycle efficiency to $32 \%$, if developing improvements in aluminum processing (i.e., Ha11 process improvements or development of carbothermic aluminum production processes) are implemented. An increase in the battery discharge efficiency to $4.5 \mathrm{kWh} / \mathrm{kg} \cdot \mathrm{Al}$ would increase fuei cycle efficiency to $29 \%$ percent. An increase to a discharge efficiency greater than $4.5 \mathrm{kWh} / \mathrm{kg} \cdot \mathrm{Al}$ is not very likely. Technology-based research on the Al-air battery strongly indicates that there exists a barrier to achieving a higher specific energy (ELTECH 1987). If both increased discharge efficiency to $4.5 \mathrm{kWh} / \mathrm{kg} \cdot \mathrm{Al}$ and improvement: in aluminum production come to fruition, the net fuel cycle efficiency would be approximately $38 \%$.

The only difference between the net fuel cycle efficiency and a utility grid-to-vehicle shaft efficiency is that the grid-to-shaft efficiency includes efficiency losses associated with the vehicle motor, which turns electricity into usable power. Table 2.1 compares the grid-to-shaft efficiencies of several vehicles.

Use of the Al-air battery coupled with a secondary battery in a hybrid vehicle would allow for the discharge of both battery systems in a manner that capitalizes on the Al-air battery's ability to provide high power levels durirg acceleration or ascent of steep grades, while the secondary battery provides steady-state energy. Consequent1y, the net vehicle efficiency would be inproved over that of an electric vehicle powered solely by an Al-air battery. The problem with such a configuration is the cost and engineering design implications of containing two battery systems in one vehicle.

(a) The BDW-series alloys were the preferred aluminum alloys (ELTECH 1987) during the preparation of this study. Prior to publication of this work, alloy preference shifted. Reviews of the new alloy indicate that the results of this study were not affected by the change. 
IABLE 2.1. Comparison of Grid-to-Shaft Efficiencies

Transmission

and

Technology Distribution

$\begin{array}{lllllll}\text { A1-air } & \text { NA } & 0.25 & \text { NA } & \text { NA } & 0.95 & 0.24 \\ \text { A1-air } & \text { NA/0.825 } & 0.25 / \text { NA } & \text { NA/0.90 } & \text { NA/0.70 } & 0.95 & 0.45\end{array}$

Hybrid (a)

Generic

Secondary

Fuel

Grid-

Battery

$\begin{array}{llllll}0.825 & \text { NA } & 0.90 & 0.70 & 0.95 & 0.49\end{array}$

(a) Assumes $20 \%$ use of the Al-air battery and $80 \%$ use of the secondary battery.

The cost associated with the fuel cycle is partialiy dependent on the actual vehicle aluminum-to-road mile efficiency (i.e., the $\mathrm{kg} \cdot \mathrm{Al}$ required per road mile) because of the selected alternative methodologies used in this study for estimating service station markup and taxes. Since the aluminumto-road efficiency is dependent on final vehicle design, a range of efficiencies was evaluated. This range covered 12.3 to $19 \mathrm{miles} / \mathrm{kg} \cdot \mathrm{Al}(19.8$ to $30.6 \mathrm{~km} / \mathrm{kg} \cdot \mathrm{Al}$ ). Using these efficiencies and applying the results described above, the cost estimates presented in Table 2.2 were prepared. The range of anode costs presented in Table 2.2 results from the four different servicecycle estimating methodologies considered. From this information, it was concluded that alloying using typical agents and base-metal purity levels of up to $99.99 \%$ aluminum was not significantly more costly than using unalloyed $99.5 \%$ aluminum.

IABLE 2.2. Range of Anode Cost Estimates

\begin{tabular}{|c|c|c|c|}
\hline \multicolumn{2}{|c|}{ Miles $/ \mathrm{kg}(\mathrm{km} / \mathrm{kg})$} & Alloyed $99.99 \%$ & Unalloyed $99.5 \%$ \\
\hline $\begin{array}{l}19 \\
14.6 \\
12.3\end{array}$ & $\begin{array}{l}(30.6) \\
(23.5) \\
(19.8)\end{array}$ & $\begin{array}{l}\$ 2.21-\$ 3.05 / \mathrm{kg} \\
\$ 2.14-\$ 3.05 / \mathrm{kg} \\
\$ 2.11-\$ 3.05 / \mathrm{kg}\end{array}$ & $\begin{array}{l}\$ 2.03-\$ 2.77 / \mathrm{kg} \\
\$ 1.96-\$ 2.77 / \mathrm{kg} \\
\$ 1.93-\$ 2.77 / \mathrm{kg}\end{array}$ \\
\hline
\end{tabular}


Table 2.3 compares the efficiency-adjusted fuel costs for the Al-air battery to an electric vehicle using a secondary battery and an internal combustion engine (ICE)-powered vehicle. Fuel costs are presented as a function of cost per $k J$ and cost per kWh of shaft output. These estimates are based on a gasoline cost of $\$ 7.77$ per MBtu (EIA 1987a), an off-peak electricity cost of 4.05 cents per $\mathrm{kWh}$, and an electrical motor efficiency of 95\%. As shown, the Al-air battery has the highest unit fuel cost. Even significant cost reductions in the aluminum industry would not eliminate this wide margin.

The efficiency-adjusted fuel costs are shown for comparison. Equitable comparisons must be made on a life-cycle cost basis, because a life-cycle cost analysis considers ali the lifetime expenses of purchasing and operating a technology, not the fuel cost alone. A complete life-cycle cost analys is was not included in the scope of this study. However, a Jet Propulsion Laboratory study (Hardy 1985) estimated the life-cycle cost of an A]-air battery-powered five-passenger vehicle to be twice as high as that of a comparable ICE-powered vehicle and $50 \%$ higher than that of a conventional secondary battery.

In summary, the following conclusions were reached:

- The expected grid-to-shaft efficiency of the Al-air battery fue 1 zycle is $24 \%$, while typical secondary battery systems have efficiencies of approximately $50 \%$.

- A significant breakthrough in Al-air battery technology and improvements in aluminum production processes must occur for the efficiency of the Al-air battery fuel cycle to exceed $35 \%$.

\section{IABLE 2.3. Comparison of Efficiency-Adjusted Fuel Cost}

\begin{tabular}{|c|c|c|c|c|c|}
\hline Technology & Charger & Battery/Motor Combination & Engine & $\$ / k+h$ & $\$ / k J$ \\
\hline Al-air & NA & $(0.47)(0.95)$ & NA & $0.56-0.80^{(b)}$ & $150-220 \times 10^{-6}$ \\
\hline Al-air Hybrid ${ }^{(a)}$ & NA/ .90 & $(0.47)(0.95) /(0.70)(0.95)$ & $\mathrm{NA} / \mathrm{NA}$ & 0.19 & $52 \times 10^{-6}$ \\
\hline Gener ic Secondary Battery & .90 & $(0.70)(0.95)$ & NA & 0.068 & $19 \times 10^{-6}$ \\
\hline ICE & NA & NA & .18 & 0.15 & $41 \times 10^{-6}$ \\
\hline
\end{tabular}

(a) Assumes $20 \%$ utilization of the Al-air battery and $80 \%$ utilization of the secondary battery. Other utilizations could be approximated using linear interpolation.

(b) Based on an anode cost of $\$ 2.11$ to $\$ 3.05 / \mathrm{kg}$ and $3.8 \mathrm{kWh} / \mathrm{kg}$ generated using the anode. 
- Using the Al-air battery in a hybrid vehicle dramatically increases net vehicle efficiency; however, this is due to use of a more efficient secondary battery for most of the supplied power.

- In a commercialized market, hydrargillite reprocessing would almost certainly need to be pursued to maintain stable aluminum and a] umina markets and to keep the consumer cost of anodes down.

- The size of hydrargillite particles at discharge from the battery system is not a limiting factor for their use for feedstock in the aluminum production process, if the hydrargillite calcining process is closely controlled.

- During repeated processing of hydrargillite through the fuel cycle, the hydrargillite should not pick up significant amounts of impurities.

- The electrolyte solution entrained with the hydrargillite upon discharge from the battery system could be washed away during hydrargillite reprocessing at negligible additional cost and energy consumption, if the aluminum production process used can tolerate low levels of electrolyte in the recycled hydrargillite. If such a tolerant aluminum process is not used, washing could be complex.

- The cost of common alloying agents is not a prime cost driver in the overall operating cost of the aluminum-air battery.

- The cost associated with the use of aluminum-alloy anodes in the aluminum-air battery is estimated to be $\$ 2.11$ to $\$ 3.05$ per kilogram anode consumed, based on current best-practice Hall process aluminum production.

The results of this analysis indicate that the cost and energy consumption characteristics of the Al-air battery system in both Al-air and Al-air hybrid electric vehicles are relatively unattractive compared to other electric- and ICE-powered vehicles. If future R\&D funds are to be spent on the Al-air battery, the following issues should be addressed:

- the value of special characteristics, such as rapid refuelability, high specific energy, and long-range capability relative to efficiency and the efficiency-adjusted fue 3 cost

- the liketihood of major efficiency breakthroughs in the battery system and fuel cycle

- specific applications that would make the Al-air battery be most attractive and whether these applications justify its development. 
If evaluation of these issues indicates poor future viability of the Alair battery system, major research efforts should be directed toward other battery systems that have higher potential for beneficial applications. Also, the transfer of information learned in Al-air battery development to other technological appiications should be strongly pursued. 
,

'

.

, 


\subsection{GENERAL COST AND ENERGY CONSUMPTION ASSESSMENT METHODOLOGY}

The Al-air battery consumes water, oxygen, and aluminum (anodes) in a chemical reaction involving an alkaline electrolyte to generate electricity and produce a reaction byproduct called hydrargillite. Theoretically, the hydraryillite, which is composed mainly of hydrated alumina $\left(\mathrm{Al}_{2} \mathrm{O}_{3} \cdot \mathrm{H}_{2} \mathrm{O}\right)$, could oe recycled into alumina and used as raw material for production of new aluminum plates though the use of the Hall process.

The battery is fundamentally different from secondary batteries in that electricity is stored in the form of the aluminum anode plates, whereas secondary batteries store electricity chemically within their electrodes. This difference in storage mechanisms necessitates careful definition of efficiencies in order to develop comparable values for the different technologies. This evaluation considers two efficiencies for the Al-air and comparison technologies: the utility grid-to-shaft efficiency and consumer purchase point of energy-to-shaft efficiency.

The utility grid-to-shaft efficiency is a measure of the battery syster's efficiency from a national energy perspective and is useful for making comparisons for prioritizing research and development (R\&D). The end points of the grid-to-shaft efficiency, the utility grid and electric vehicle motor shaft, were selected, because at both of these points the form of energy is the same for the Al-air and conventional secondary batteries. In the case of the Al-air battery; the electricity is used in aluminum plates to produce anodes for the battery: in the case of a secondary battery, the electricity travels over transmission and distribution lines to the end-user, where it is used to directly charge the battery. To calculate the grid-toshaft efficiency for the Al-air battery, all the direct energy consumed during the production of the aluminum anodes from alumina and recycling of hydrargillite (i.e., the complete fuel cycle), plus motor and auxiliaries inefficiencies, must be considered.

The consumer, however, is interested only in the electric vehicle efficiency that affects the cost to operate the vehicle; thus, a second efficiency, the consumer purchase point of energy-to-shaft efficiency, is 
needed. This efficiency, coupled with the cost of fuel, represents the efficiency-adjusted fuel cost to the consumer. The consumer efficiency for an Al-air electric vehicle is represented by the total amount of energy received from the vehicle shaft divided by the theoretical energy yield of the aluminum anode. In the case of a secondary battery, the consumer efficiency is represented by the total amount of energy out of the vehicle shaft divided by the amount of energy input into the battery system as measured at the purchase meter. Thus, the consumer efficiency of a secondary battery accounts for charger losses and motor inefficiencies. The efficiencyadjusted fuel cost is represented by the purchase cost per unit of energy, whether it be in the form of electrical energy or an aluminum anode, divided by the consumer efficiency. The efficiency-adjusted fuel cost is the cost per unit of energy (e.g., dollars-per-kWh) the consumer receives from the electric vehicle system.

An integrai part of the utility grid-to shaft efficiency of the Al-air battery is the battery's fuel cycle. The fuel cycle begins with alumina, which is used as a feedstock to an aluminum production process. The molten aluminum from the production process is cast and sheared into anode form for use in the battery. The anodes are then transferred to service stations, where they are installed in Al-air battery-powered vehicles. During the operation of an Al-air battery-powered vehicle, it would be necessary to remove hydrargillite, add water, and possibly add electrolyte three times during the life of one set of plates. Figure 3.1 illustrates this fue $i$ cycle.

In order to develop cost and energy consumption estimates, it is necessary to assess energy consumption and the associated manufacturing and operational costs at each step of the fuel cycle. For estimation purposes, the fuel cycie is divided into three major parts (see Figure 3.1): 1) the service cycle, 2) hydrargillite reprocessing, and 3) anode manufacture. These three parts of the fuel cycle and the specific assessment methodologies for them are addressed in Sections 4.0, 5.0, and 6.0, respectively. 


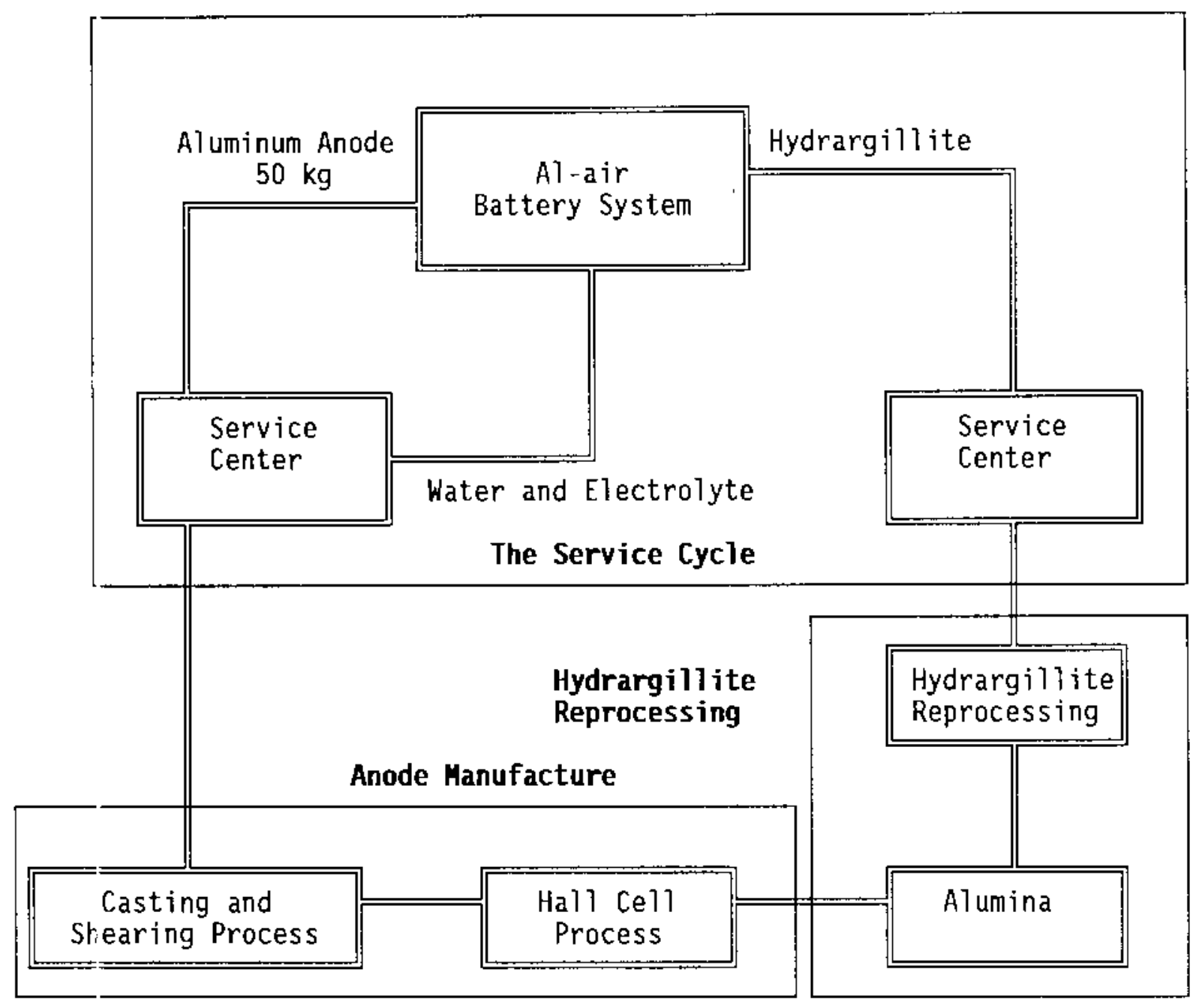

FIGURE 3.1. Fuel Cycle for the Aluminum-Air Battery 


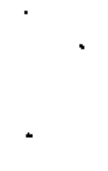




\subsection{THE SERVICE CYCLE}

Juring the operation of the Al-air battery, a reaction byproduct called hydrargillite is produced. A precise composition of the hydrargillite cannot be specified, because the separation processes involved within the battery systen have not yet been finalized. The primary developer of the Al-air battery system, ELTECH Systems Corporation, has done experimental work in this area and developed some guidelines for the separation which would occur within the electric vehicle power cell.

The composition of the liquid phase entrained with hydrargillite upon removal from the battery will depend on whether the hydrargillite is washed with water, and if this is the case, how efficient this washing step is. (a) Withost washing, the liquid phase would be of the same composition as the battery's electrolyte, approximately 4 to 5 molar sodium hydroxide ( $\mathrm{NaOH}$ ) or potassium hydroxide $(\mathrm{KOH}) .($ a) Currently, $\mathrm{KOH}$ is the preferred electrolyte. (b) Due to the anticipated loss of electrolyte without washing, the battery's separation process will at least include a minimal washing step utilizing the make-up water. (a)

while the quantity and chemical content of liquid entrained with the hydrargillite has not yet been finalized, it is estimated that it will vary between $15 \%$ and $30 \%$ of dry hydrargillite by volume, with the solution being approximately 1 molar alkaline. The value of $30 \%$ represents the liquid fraction based upon free sett]ing; 15\% includes some type of additional processing to remove water $(b)$. For the purpose of preparing the estimates presented in this study, a liquid fraction of 0.15 was assumed. A higher liquid fraction would increase hydrargillite storage space requirements at service stations and hydrargillite shipping costs to the reprocessing facility; it could possibly also require a liquid separation step before reprocessing.

(a) Personal correspondence with Lawrence Frank of ELTECH Systems Corporation, August 24, 1987.

(b) Personal communication with Marilyn Nicksa of ELTECH Systems Corporation, May 2, 1988. 
The service cycle is the most difficult part of the fuel cycle to characterize, because there is no operating experience upon which to base cost estimates. Previous Al-air battery studies (Hudson and Putnam 1980; Cooper 1980; and Cooper 1984) have based estimates on similarities between the perceived A1-air battery-powered electric vehicle operation characteristics and the refueling and fuel taxation characteristics of an internal combustion automobile. There is no new information available pertaining to the service cycle since the most recent study (Cooper 1984) was completed, except for the change from $1600 \mathrm{~km}$ to $1200 \mathrm{~km}$ as the nominal driving distance between anode replacements. Therefore, Cooper's previous estimate was reviewed and updated to 1987 dollars. Where it was deemed appropriate, Cooper's methodology was revised or compared to alternative methodologies.

The service cycle includes four basic operations: 1) installation of the anodes, 2) removal of hydrargillite, 3) addition of water and electrolyte, and 4) shipment of the hydrargillite to a reprocessing facility. It is assumed that anodes are added in increments of $50 \mathrm{~kg}$, the current design quantity. The installation of $50 \mathrm{~kg}$ of aluminum anode every three times hydrargillite is removed and water and electrolyte are added is the current baseline design. The actual distance between anode replacements will depend on the vehicle design, vehicle duty cycle, and battery system aluminum fuel efficiency. The relationship of importance is that 50 kilograms of anode are installed for every three discharges of hydrargillite and additions of water.

Cooper (1984) based the annual service center markup on aluminum anode fuel as being equivalent to the markup on gasoline for a vehicle of equivalent characteristics. For a gasoline-powered vehicle averaging 25 miles per galion and 10,000 miles per year, the total annual markup up is $\$ 40$ based on the average service center markup of 10 cents per gallon. This is equivalent to a markup of $\$ 0.004$ per mile. As explained in Section 7.0 , the $\$ 0.004$ per mile markup is equivalent to $\$ 0.049$ to $\$ 0.076$ per kilogram of anode for the range of vehicle efficiencies evaluated in this study. Cooper developed this estimate as a lower-bound limit. As an upper bound, Cooper estimated an applicable charge for anode installation. At a burdened labor rate of $\$ 10$ per hour and 15 minutes allowed for anode installation, a charge of $\$ 2.50$ was estimated. This charge would be in addition to the $\$ 40$ annual markup 
estimated at the lower bound, which covers hydrargillite removal, addition of water and electrolyte, and service center expenses.

Cooper's anode installation estimate is for the installation of $81.6 \mathrm{~kg}$ of aluminum and is in 1984 dollars. Maintaining Cooper's methodology, but using a $\$ 25$ per hour (1987 dollars) burdened labor rate and 15 minutes for insta'ling $50 \mathrm{~kg}$ of aluminum anode, PNL estimated the anode installation charge as $\$ 6.25$. The installation time is not anticipated to be significantly shorter for $50 \mathrm{~kg}$ than for $81.6 \mathrm{~kg}$. Because both sets of anodes (50 $\mathrm{kg}$ and $81.6 \mathrm{~kg}$ ) are unmanageable manually, a small jib crane would be required. The use of the crane effectively negates the weight difference for installation purposes.

The high end of Cooper's estimate is probably the most realistic of the two service station markup scenarios. It is highly likely that two types of A)-ai" battery-powered electric vehicle service centers would exist, if a large number of vehicles were placed in commercial service. The first type would be full-service centers which would be capable of installing plates, handling hydrargillite discharge, and adding water and electrolyte. The second type would only handle hydrargillite discharge and water and electrolyte addition. Because hydrargillite discharge and water and electrolyte addition occurs three times as often as plate installation, the second type of senvice facility would be more prevalent. The high end of Cooper's estimate is more realistic, because it directly covers the full cost associated with jlate installation, while the low end of Cooper's estimate does not.

In alternative methodology is to assume a standard percentage markup on the wolesale price of the aluminum anodes, in addition to the anode installation charge. This percentage covers service station expenses and profit. Based on other high-turnover commodities, a $10 \%$ markup is assumed. The plate installation charge is again estimated as $\$ 6.25$, based on 15 minutes for installation and a $\$ 25$ per hour labor rate. This method treats the aluminum anodes as a commodity rather than as a fuel. While the anodes have generally been treated as a fuel in previous studies, it is quite possible they will not be treated as such if the Al-air battery develops a commercial market. 
In addition to the refueling charges, cooper equated the annual fuel taxes paid by a gasoline-powered vehicle to be applicable to an Al-air battery-powered vehicle of equivalent characteristics. Following Cooper's logic, using the long-term average for fuel taxes of $\$ 0.30$ per gallon (see Table 3.1), and assuming equivalence to a 25-mile-per-gallon gasoline-powered vehicle that travels 10,000 miles per year, the net tax per mile is $\$ 0.012$.

An alternative method of taxation is to assume a tax based on a percentage of retail cost. As shown in Table 4.1, the long-term fuel tax rate is $39 \%$. This rate would be applied to the aluminum anode cost after the retail markup.

Shipping of the hydrargillite to the reprocessing facility is estimated to cost $\$ 0.0292$ per $\mathrm{kg}$ of anode. This estimate assumes a standard weightlimited load of 45,000 lbs, a shipping distance of 125 miles, and a per-mile shipping cost of \$1.45. The average shipping distance of 125 miles is based on a study (Hudson and Putnam 1980) that estimated the average shipping distance in a mature Al-air battery-powered electric vehicle market.

Direct energy consumption during the service cycle is 1 imited to hydrargillite transportation energy. Based on energy consumption of 1110 Btu/ton.mile (Cooper 1984), the total energy consumption per shipment is 3.12 $\times 10^{6} \mathrm{Btu}\left(3.29 \times 10^{6} \mathrm{~kJ}\right)$. At $3.29 \mathrm{~kg}$ of hydrargi 11 ite per $\mathrm{kg}$ of a 7 uminum produced (Hudson and Putnam 1980), the transportation energy consumption is $529 \mathrm{~kJ} / \mathrm{kg} \cdot \mathrm{A} 1$.

In summary, the costs associated with the service cycle aspects have been examined such that four estimates are possible. The bases for the four estimates are as follows:

1. Assume the station markups inciude a dollar-per-mile markup, an anode installation charge, and a percentage for taxes.

2. Assume the station markups include a dollar-per-mile markup, an anode installation charge, and a dollar-per-mile tax charge.

3. Assume the station markups include an anode installation charge, a general percentage markup, and a percentage for taxes.

4. Assume the station markups include an anode installation charge, a general percentage markup, and a dollar-per-mile tax charge. 
Using these bases, the four service-cycle estimates as a function of kilograms of aluminum and miles traveled were developed. These estimates do not include the estimated shipping cost of $\$ 0.0292$ per $\mathrm{kg}$ :

1. $\$ 0.004 / \mathrm{mile}+\$ 0.125 / \mathrm{kg} \cdot \mathrm{Al}+39 \%$ of the total, including anode purchase cost

2. $\$ 0.004 / \mathrm{mile}+\$ 0.125 / \mathrm{kg} \cdot \mathrm{Al}+\$ 0.012 / \mathrm{mile}$

3. $\$ 0.125 / \mathrm{kg} \cdot \mathrm{Al}+10 \%$ of the anode purchase cost $+39 \%$ of the total, including anode purchase cost

4. $\$ 0.125 / \mathrm{kg} \cdot \mathrm{A} 1+10 \%$ of the anode purchase cost $+\$ 0.012 / \mathrm{mile}$.

Basec on the additional information presented in Section 7.0 , these estimates can te converted to the following four estimates, respectively, for alloy anodes made using $99.99 \%$ Al base-metal:

1. $\$ 1.13$ to $\$ 1.09$ per $\mathrm{kg}$ of anode

2. $\$ 0.36$ to $\$ 0.46$ per $\mathrm{kg}$ of anode

3. $\$ 1.30$ per $\mathrm{kg}$ of anode

4. $\$ 0.50$ to $\$ 0.58$ per $\mathrm{kg}$ of anode.

These estimates include the estimated shipping cost of $\$ 0.0292$ per $\mathrm{kg} \bullet \mathrm{Al}$. The range of the estimates arises from the variation of costs over the vehic le electricity-to-road mile efficiency range of 12.3 to $19 \mathrm{kWh} / \mathrm{mile}$. 
IABLE 4.1. Long-Term Gasoline Taxes Versus Retaj1 Cost

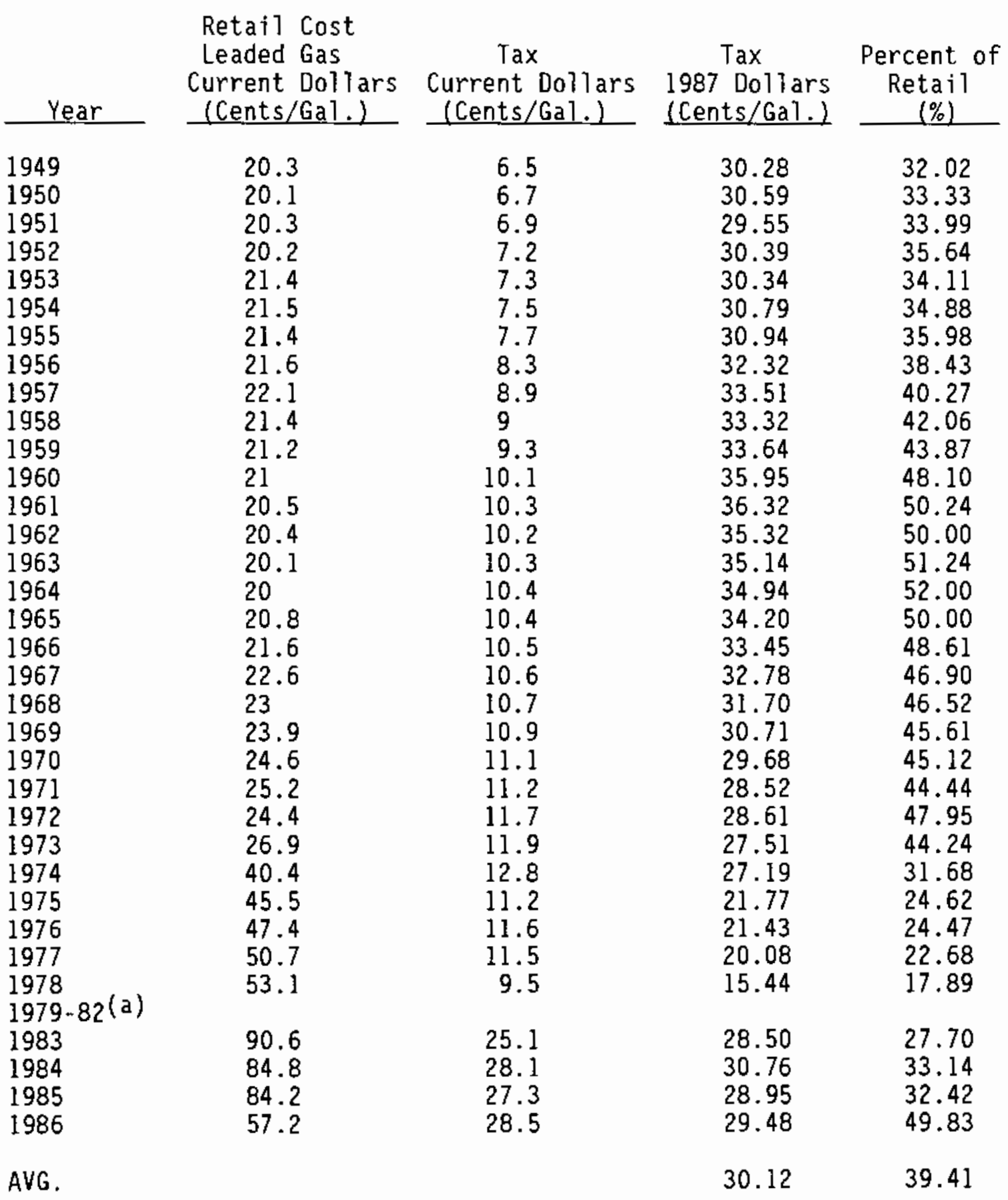

(a) Consistent data for the years 1979 to 1982 were not obtainable from the U.S. Department of Commerce or the Energy Information Administration.

Sources: U.S. Department of Commerce 1977, 1978, 1979, 1980, 1981, 1982, 1983, 1985, 1986, and 1987; Energy Information Administration $1987 b$. 


\subsection{HYDRARGILLITE REPROCESSING}

l'pon delivery to a hydrargillite reprocessing facility, the damp hydrargillite is assumed to have a liquid content of $15 \%$ by volume. This liquid is approximately a 1 molar alkali solution. The reprocessing steps used must refine the hydrargillite to a commercially pure cell-grade alumina. This will allow its use as a feedstock for the manufacture of new anodes. This chapter assesses the cost and associated direct energy consumption from the $t$. me the damp hydrargillite is delivered to a reprocessing facility, through the processing steps, until a commercial cell-grade alumina is achieved. An alternative operating scenario has suggested disposal of the hydrargillite instead of reprocessing. The ramifications of such a scenario are $d$. scussed in this chapter.

in current aluminum manufacturing, commercial-grade alumina is usually obtained from the processing of bauxite into alumina. The commercial process by which bauxite is refined into alumina is called the Bayer process. Specifically, the Bayer process consists of digesting bauxite in a hot caust $\mathrm{C}$ soda solution, removing insoluble impurities, precipitating hydrated alumina $\left(\mathrm{Al}_{2} \mathrm{O}_{3} \cdot \mathrm{H}_{2} \mathrm{O}\right)$, and finally transforming the precipitate by calcination to cormercially pure alumina (i.e., a few hundredths of one percent of impurties) (Shen 1981, p. 12). Figure 4.1 presents a schematic of the Bayer Proce:is.

"o generate one (metric) tonne of molten aluminum, 1.90 to 1.95 tonnes of al umina are required (Shen 1981, p. 14). For calculational purposes, the averaye of this range, 1.925 tonnes, is used. Based on one tonne of aluminum produlition, the energy inputs attributed to the Bayer process based on "bestpractice" are presented in Table 5.1.

For recycling hydrargillite into alumina, it is theorized that processing would strongly resemble the last few steps of the Bayer process. Previous cost and energy consumption estimates for hydrargillite reprocessing have assumed that only the calcining step will be required. Because it is likely that the hydrargillite has an entrained 1 molar alkali solution, first washing, then calcining will be required at a minimum. Currently, the alkali 


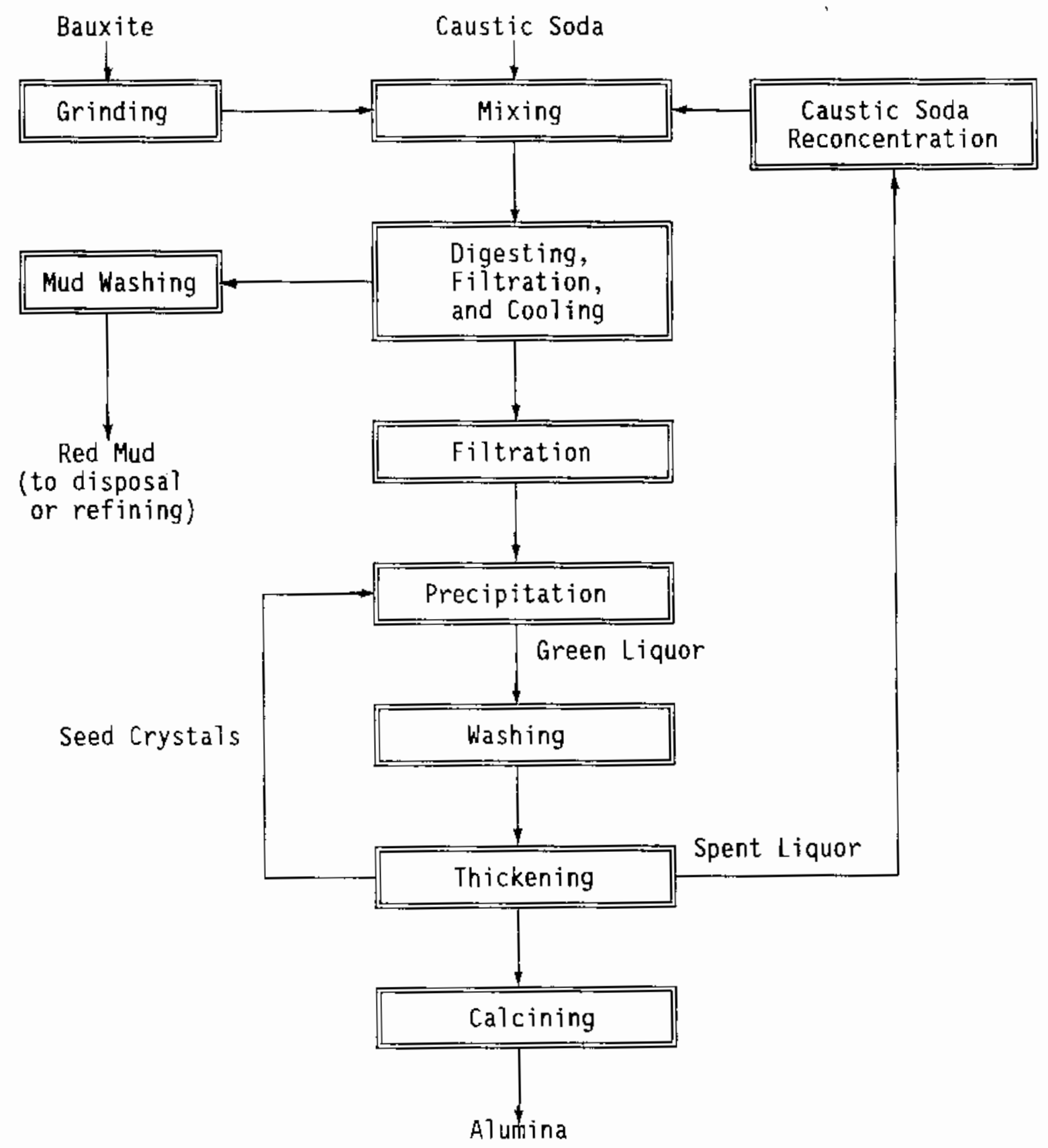

FIGURE 5.1. Schematic of the Bayer Process 
TABLE 5.1. "Best Practice" Energy Inputs to the Bayer Process

$\frac{\text { Energy Input }}{\text { Steam to Digester }}$
Fossil Fuel to Calciner
Other Energy

(a) Shen 1981, p. 14 .

(b) Lussky 1980 , p. 73.

$\frac{\text { Energy Value }}{23 \times 10^{6} \mathrm{~kJ} / \text { tonne } \cdot A 7}$ (a)
$3.2 \times 10^{6} \mathrm{~kJ} /$ tonne $\cdot \mathrm{Al}^{(\mathrm{b})}$
$2.3 \times 10^{6} \mathrm{~kJ} /$ tonne $\cdot \mathrm{Al}^{(\mathrm{a})}$

solution preferred by the battery developer is potassium hydroxide (KOH). (a) The $\mathrm{H}_{i} 11$ process would be less tolerant to the presence of $\mathrm{KOH}$ than it would be to the alternative alkali, sodium hydroxide $(\mathrm{NaOH})$. Whichever electrolyte is firially selected, if alkali concentrations are too high for producing a) umirum anodes of acceptable purity, excess electrolyte must be removed from the hydrargillite in a washing step before calcining.

A second technical issue identified by Sen (1988) relates to the size of the hydrargillite particles upon removal from the battery's separator. Currently', hydrargillite particles produced by the Al-air battery system's separitor are 10 microns in size. The battery developer's goal is a particle size sf 40 microns. Even particles of 40 microns are unacceptable for use in the Hill process. There are two reasons for this. First, alumina is often fed to the Hall (reduction) cells using screw feeders, which become jammed when handling small particles. New reduction cell capacity is likely to include pneumatic transport of alumina. In this type of transport system, small alumina particles cause fluidization effects, which inhibit proper transport. (b) Second, the alumina is added to the reduction cells by being dropped from an opening above the cell. Alumina of small particle sizes tends to form dust clouds in the potroom rather than settling into the moltell contents in the cell. Aluminum companies generally prefer alumina particle sizes of 45 to 150 microns. The small particle problem is easily

(a) Personal communication with Marilyn Nicksa, ELTECH Systems Corporation, May 5, 1988.

(b) Personal communication with Gary Tarcy, Alcoa Aluminum Company, May 5, 1988. 
remedied during calcining. By carefully controlling the calcining temperature, the water entrained in the hydrargillite is driven off, and the hydrargillite particles agglomerate into alumina particles of adequate size.

A third technical issue is the possibility of ever-increasing impurity levels of impurities, particularly iron, caused during repeated processing through the fuel cycle. Assuming proper handling of the hydrargillite during transport to the reprocessing facility, iron contamination is most likely to occur within the Hall cell. In the Hall cell, iron often is unintentionally added in small amounts by iron tools used in the aluminum production process and iron rods that can be used to support the carbon anodes used in the reduction cell. However, this addition of iron is expected to be counterbalanced by the volatization of some iron as iron oxides, which escape from the reduction cell during the aluminum production process. Therefore, it is anticipated that iron levels will stay relatively low through repeated fuel cycles.

Because there is uncertainty as to exactly what process steps would be required, two hydrargillite reprocessing scenarios have been evaluated: 1) calcining only, and 2) washing and calcining. Evaiuation of the direct energy consumption during hydrargillite reprocessing is a straightforward process. As shown in Table 5.1, the energy inputs to the Bayer process are divided into three categories: steam to digester, fossil fuel to calciner, and other energy. Because none of the hydrargilijte reprocessing scenarios use a digester, the steam to digester energy input is not applicable to hydrargillite reprocessing. However, both scenarios include calcining; therefore, $3.2 \times 10^{6} \mathrm{~kJ} /$ tonne.A1 can be attributed to both hydrargillite reprocessing scenarios. The "other energy" category represents energy consumption by process pumps, motors, conveyors, etc.; that was assumed to be divided equally among the ten Bayer process steps presented in Figure 5.1. This is equivalent to approximately $230,000 \mathrm{~kJ} /$ tonne.Al per Bayer process step. Assuming this relationship holds true, the two hydrargillite reprocessing scenarios would use a total of $0.23 \times 10^{6}$, and $0.46 \times 10^{6} \mathrm{~kJ} /$ tonne.Al of "other energy," respectively. Direct energy consumption for each scenario is presented in Table 5.2 . 
IABLE 5.2. Direct Energy Consumption of Hydrargi17ite Reprocessing Scenarios

Scenario

\#1 salcining

\#2 salcining and washing
Direct Energy Consumption, $\mathrm{kJ} /$ tonne $\cdot$ Alumina

$3.43 \times 10^{6}$

$3.66 \times 10^{6}$

Hydrargillite reprocessing is assumed to take place in a dedicated facility that has an annual production capacity of one million tons (0.91 million tonnes) of alumina. A capital and operating cost estimate was prepared for each of the reprocessing scenarios postulated. The estimates are based on cost data presented in Cost Estimate of the Bayer Process for Producing Alumina (Kramer and Peters 1983). To determine the total reprocessing cost per tonne of alumina produced, the plant capital cost per tonne of alumina production capacity was multiplied by a fixed charge rate $\left(F C R_{p}\right)$, the working capital cost per tonne of alumina production capacity was multiplied by a second fixed charge rate $\left(F C R_{w C}\right)$, and the variable operating cost per tonne of alumina was added to the sum of these two values. This yields the total reprocessing cost of hydrargillite per tonne of alumina produced. Details of the economic methodology are presented in Appendix A.

For the reprocessing scenario that assumes calcining only, the total estimated capital cost for the calcining plant, including working capital, is $\$ 109.4$ million. Table 5.3 presents the capital cost estimate for the calcining plant. The estimated operating costs for the calcining plant are $\$ 29.23$ per tonne of alumina produced. Table 5.4 presents the total annual operating cost estimate. Details of the capital and operating cost estimates are presented in Appendix $B$. To determine the total reprocessing costs, the plant capital cost (including working capital) was multiplied by a fixed charge rate of 0.11 , and this value was added to the estimated operating costs. This yields a total reprocessing cost of $\$ 42$ per tonne of alumina produced, which is equivalent to $\$ 81$ per tonne of aluminum produced. 
IABLE 5.3. Capital Investment Cost Estimate for a Calcining Facility for Hydrargillite Reprocessing

Cost Elements

Installed Capital Equipment

Field Indirects

Engineering

Administration

Contingency

Contractor's Fee

Plant Facilities

Plant Utilities

Working Capital

Capitalized Startup Costs

Total Capital Investment
1987 dollars

$\$ 36,104,700$

$3,610,500$

$3,971,500$

$1,985,800$

$6,850,900$

$2,626,200$

$5,515,000$

$6,618,000$

$41,401,000$

672,800

$\$ 109,356,400$

TABLE 5.4. Annual Operating Cost Estimate for a Calcining Facility for Hydrargil1ite Reprocessing

\section{Cost Elements}

Utilities

Direct Labor

Plant Maintenance

Payroll Overhead

Operating Supplies

Indirects

Total Annual Operating Cost
1987 dollars

$\$ 19,527,400$

756,200

$3,351,300$

904,500

335,100

$1,643,000$

$\$ 26,517,500$

For the reprocessing scenario that assumes washing and then calcining, the total estimated capital cost for the calcining plant (including working capital) is $\$ 117.3$ million. Table 5.5 presents the capital cost estimate for the washing/calcining plant. The estimated operating costs for the plant are $\$ 31.08$ per tonne of ai umina produced. Table 5.6 presents the operating cost estimate. Details of the capital and operating cost estimates are presented in Appendix B. To determine the total reprocessing costs, the plant capital cost, including working capital, was multiplied by a fixed charge rate of 0.11 , and this value was added to the estimated operating costs. This yields a total reprocessing cost of $\$ 45$ per tonne of alumina produced, which is equivalent to $\$ 87$ per ton of aluminum produced. 
IABLE 5.5. Capital Investment Cost Estimate for a Washing/Caicining Facility for Hydrargillite Reprocessing

\begin{tabular}{l} 
Cost Elements \\
\hline Installed Capital Equipment \\
Field Indirects \\
Engineering \\
Administration \\
Contingency \\
Contractor's Fee \\
Plant Facilities \\
Plant Utilities \\
Working Capital \\
Capitalized Startup Costs \\
Total Capital Investment
\end{tabular}

$\underline{1987 \text { dollars }}$

$\$ 38,307,900$

$3,830,800$

$4,213,900$

$2,106,900$

$7,268,900$

$2,786,400$

$5,851,500$

$7,021,800$

$45,230,300$

713,900

$\$ 117,332,300$

TABLE 5.6. Annual 0perating Cost Estimate for a Washing/Calcining Facility for Hydrargillite Reprocessing

\begin{tabular}{lr}
\multicolumn{1}{c}{ Cost Elements } & 1987 dollars \\
\hline Utilities & $\$ 20,863,900$ \\
Direct Labor & 756,200 \\
Plant Maintenance & $3,555,600$ \\
Payroll Overhead & 943,500 \\
Operating Supplies & 355,600 \\
Indirects & $1,724,700$ \\
& \\
Total Annual Operating Cost & $\$ 28,199,500$
\end{tabular}

One operating scenario for the Al-air battery suggests disposal rather than reprocessing of the hydrargillite. This is viable in the near term when only a small number of Al-air batteries would be in operation. However, in the long term, the use of a large number of Al-air batteries would create tremendous demands on the supply of primary aluminum. Therefore, recycling of the hydrargillite would be required to maintain a stable primary aluminum market and a stable supply of replacement anodes.

In a study (Hudson and Putnam 1980) that inciuded market penetration estimates, it was projected that in a production year in which sales of 
3 million aluminum-air battery-powered automobiles occurred(a) and five million were already in operation, the following demands would be placed on the aluminum industry:

- primary aluminum required for anodes in new cars would equal 224,800 metric tonnes (247,280 tons)

- recycled aluminum for replacement aluminum anodes to support the eight million vehicles in the fleet would equal 6.53 million metric tonnes (7.20 million tons).

These projections assume a $19.6 \mathrm{~km} / \mathrm{kg} \cdot \mathrm{Al}(12.2 \mathrm{miles} / \mathrm{kg} \cdot \mathrm{Al})$ vehicle efficiency. The demand projections for replacement anodes would be inversely proportional to vehicle efficiency. The demand for primary aluminum for initial anodes (247,280 tons) represents a $1.8 \%$ increase over the 27.7 billion pounds of aluminum produced in the world in 1987 (Light Metal Age $1988, p .45)$. This demand would develop over 5 to 10 years and could be met by aluminum producers. The demand created by the need for replacement anodes is another matter. The 7.20 million tons of replacement anodes represents an $52 \%$ increase in demand from 1987 world aluminum production. This demand would exert significant pressures on world aluminum prices, and therefore, the price of primary aluminum could increase dramatically. For these reasons, disposal of hydrargillite and purchase of new aluminum is a poor scenario to pursue in the long term. If a major market penetration of Al-air battery-powered vehicles occurs, dedicated hydrargillite and anode manufacture plants would provide a more stable supply base.

Table 5.7 summarizes the two viable long-term hydrargillite reprocessing scenarios examined in this chapter, calcining, and washing and calcining. Given the accuracy of the estimates, the difference between the two scenarios is negligible. For the purpose of generating the total fuel cycle estimates, the average energy consumption and cost of the two scenarios was used. The conversion factor used to convert energy consumption to a kWh/tonne-Al bas is was $10550 \mathrm{~kJ} / \mathrm{kWh}$.

(a) As a point of reference, 1986 new car sales in the U.S. totaled $11,450,000$ (U.S. Department of Commerce 1987). 
TABLE 5.7. Direct Energy Consumption and Cost Estimates for Reprocessing of Hydrargillite

Scelario

\#1

$\$ 2$
Energy Consumption

$3.43 \times 10^{6} \mathrm{~kJ} /$ tonne $\cdot \mathrm{Al}=325 \mathrm{kWh}$

$3.66 \times 10^{6} \mathrm{~kJ} /$ tonne $\left.\cdot \mathrm{A}\right]=347 \mathrm{kWh}$
Reprocessing Cost

$\$ 81$ per tonne of aluminum

$\$ 87$ per tonne of aluminum 
-

.

, 


\subsection{ANODE MANUFACTURE}

Currentiy, the production of primary aluminum consists of two major processes, the refinement of bauxite ore into commercially pure alumina $\left(\mathrm{Al}_{2} \mathrm{C}_{3}\right)$ and the reduction of alumina to form molten aluminum and byproducts. The nost common reduction process and the one examined in this review is the Ha11-Heroult process. Several aluminum manufacturing process improvements were reviewed to identify the potential for reduction in the direct energy consumption of anode manufacture.

When purified alumina is reduced to molten aluminum using the HallHeroult process (commonly called the Hall process in North America), the alumina is dissolved in an electrolytic cell filled with molten cryolite. Through the use of electrical current, the alumina is reduced. In addition to elactricity, energy is supplied to the $\mathrm{Hall}$ cell through a consumable carbor anode. The oxygen from the alumina reacts with the carbon anode of the $\mathrm{c} \geq 11$ to form carbon dioxide, which is emitted from the cell. The aluminum is heavier than the electrolyte in the cell and, therefore, settles to tha bottom of the bath. When a sufficient amount of aluminum has settied, it is siphoned from the bath. The molten aluminum is then sent to a holding furnace until it is shipped to nearby plants or to a casting operation. A Hall rrocess schematic is presented in Figure 6.1. The "best-practice" energ. inputs associated with the production of one tonne of aluminum are preseited in Table 6.1 , based on prebaked anode technology. (An alternative anode technology is Soderberg. This technology avoids the use of molding, roddilig, and baking processes at the expense of lower cell efficiency. Consequent7y, the technologies are roughiy equivalent in cost and energy consunption.)

n a study by Reynolds Aluminum (McMinn and Branscomb 1981), it was concluded that the lowest-cost anode plates could be made by going directly from nolten Hall cell metal to a continuous caster, where an anode strip is formed. A shearing machine cuts the strip into the appropriate Tengths. 


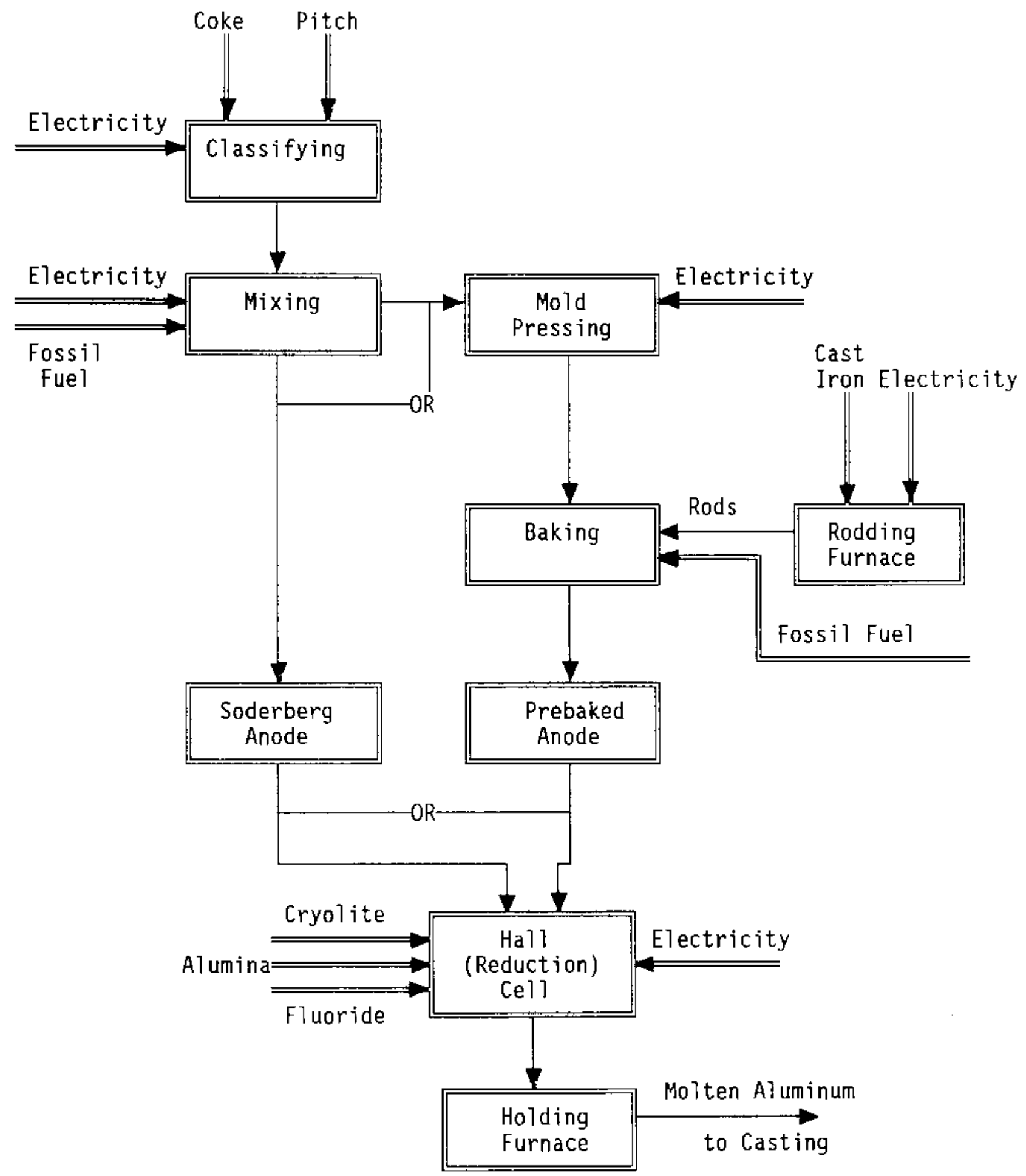

FIGURE 6.1. Hall Process Schematic 
IABLE 6.1. "Best Practice" Energy Inputs to the Hall Process

Input

Electricity to classifying process

Electricity to mixing process

Fossil fuel to mixing process

Electricity to mold pressing

Electricity to rodding process

Fossil Fuel to baking process

Electricity to the Hall Cell

Electricity to the holding furnace

Fossil fuel to holding furnace
Enerqy Value

$220 \mathrm{kWh} /$ tonne $\cdot \mathrm{A} 1$

$110 \mathrm{kWh} /$ tonne.A1

$0.53 \times 10^{6} \mathrm{~kJ} /$ tonne.A1

$275 \mathrm{kwh} /$ tonne.A1

$220 \mathrm{kWh} /$ tonne.Al

$0.22 \times 10^{6} \mathrm{~kJ} /$ tonne. Al

$13,305 \mathrm{kWh} /$ tonne.A1

$110 \mathrm{kWh} /$ tonne.A1

$5.0 \times 10^{6} \mathrm{~kJ} /$ tonne $\cdot \mathrm{A} 1$

Fina'ly the anodes are packaged for shipment. Table 6.2 presents the energy consumption estimates associated with the continuous casting of one tonne of a 7 um inum anodes.

TABLE 6.2. Energy Inputs to the Continuous Casting/Shipping Process

Input
Electricity to casting
Electricity to shearing
Electricity to packaging
Fossil fuel to shipping

Energy Value

$125 \mathrm{kWh} /$ tonne. A1

$53 \mathrm{khh} /$ tonne.AT

$92 \mathrm{kWh} /$ tonne. Al

$0.16 \times 10^{6} \mathrm{~kJ} /$ tonne. $\mathrm{A} 1$

The total energy consumption during aluminum production is $14,240 \mathrm{kmh}$ plus $5.75 \times 10^{6} \mathrm{~kJ}$ per tonne of aluminum produced. In addition, the casting/ shipping process requires $270 \mathrm{kWh} /$ tonne $\cdot \mathrm{Al}$ and $0.16 \times 10^{6} \mathrm{~kJ} /$ tonne $\cdot \mathrm{Al}$. The total primary energy consumption is therefore $14,510 \mathrm{kWh} /$ tonne AT plus $5.9 \times 10^{6}$ $\mathrm{kJ} /$ tonne.Al. Using a conversion factor of $10,550 \mathrm{~kJ} / \mathrm{kWh}$, total direct energy consumption is equivalent to $15.1 \mathrm{kWh} / \mathrm{kg} \cdot \mathrm{Al}$.

The cost of anode production was estimated by adjusting the time-averaged cost of the standard aluminum ingot to reflect the differences in anode production from standard ingot production. The cost of aluminum ingot used as the basis is the average "real-dollar" market cost of aluminum over the past twenty years. The cost for each year of this period is presented in Table 6.3. The time-adjusted average cost is $\$ 0.72 / 1 \mathrm{~b}(\$ 1.59 / \mathrm{kg})$ (1987 dollars). Table 6.4 presents the adjustments made to the time-adjusted 
TABLE 6.3. Aluminum Ingot Prices from 1967 to 1987 (cents per pound)

Actual Price

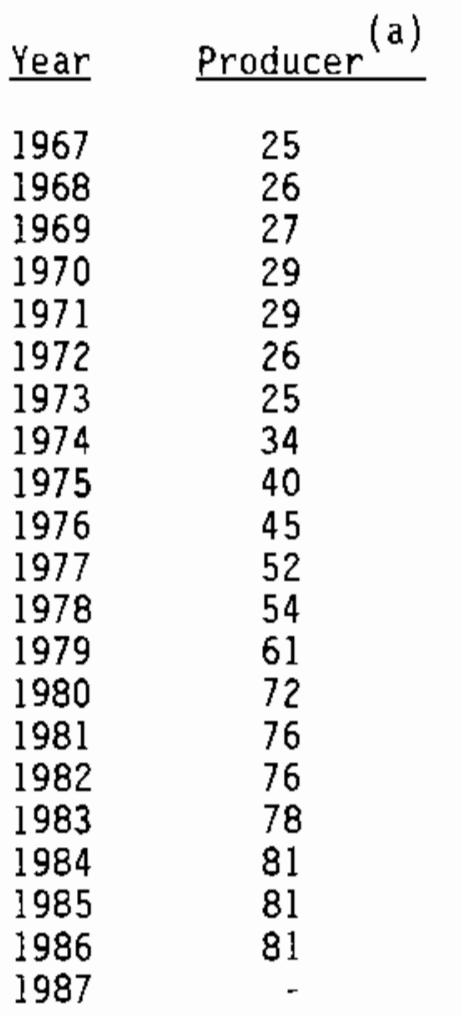

Average
1987 dollars

Producer $\quad$ Market

77

77

76

78

74

64

58

72

78

83

91

88

91

99

95

90

89

88

86

84

- 71

82

72

(a) Annual average of major producers' quoted prices for unalloyed primary aluminum ingot.

(b) Annual average market or spot prices as reported by Metals Week.

average ingot cost to develop the anode cost estimate. The final delivered cost estimate as presented in Table 6.4 is $\$ 1.67 / \mathrm{kg}$. The cost estimate of $\$ 1.67 / \mathrm{kg}$ is the total amount incurred during each fue? cycle. This estimate does not include the value of the base alumina that is not consumed during the fuel cycle. The base alumina travels through the fuel cycle being used to produce aluminum, converted to hydrargillite, and reprocessed to alumina. The value of alumina is $\$ 0.308 / \mathrm{kg} \cdot$ Al (see Table 6.4). Adding this value to the anode fuel cycle cost of $\$ 1.67 / \mathrm{kg}$ yields a wholesale anode cost of $\$ 1.98$ for alloyed anodes made from $99.99 \% \mathrm{Al}$. The wholesale cost of unalloyed $99.5 \% \mathrm{Al}$ anodes is estimated as $\$ 1.80$. The wholesale cost is important when 
IABLE 6.4. Anode Cost Estimate (1987\$)

Time-adjusted delivered cost of AT ingot $\$ 1.588$

Less ingot casting costs(a)

$-0.060$

Less the cost of new alumina saved (b)

$-0.308$

Plus continuous casting costs $(\mathrm{c})$

$+0.211$

Plus shearing and stacking $(d) \quad+0.060$

Plus purity cost $(e)$

Plus alloy enhancement cost $(f)$

$+0.106$

Total cost of the anode per fuel cycle(g)

$+0.073$

$\$ 1.67$

(a) Based on a 1980 estimate by LLNL using engineering judgment. The LLNL estimate of $\$ 0.043 / \mathrm{Kg}$ was adjusted to $1987 \$$ using GNP implicit price deflators.

(b) Based on 1.925 tonnes of alumina per tonne of aluminum and a market price for alumina of $\$ 160$ per tonne (Arthur D. Little 1988).

(c) Based on a 1980 estimate by Reynolds Aluminum (McMinn and Branscomb 1981). The Reynolds estimate of $\$ 0.15$ was adjusted to $1987 \$$ using GNP implicit price deflators.

(d) Based on a 1980 estimate by Reynolds Aluminum (McMinn and 8ranscomb 1981). The Reynolds estimate of $\$ 0.043$ was adjusted to $1987 \$$ using GNP implicit price deflators.

(e) Based on a 1980 estimate by Reynolds Aluminum (McMinn and Branscomb 1981). The Reynolds estimate of $\$ 0.077$ was adjusted to $1987 \$$ using GNP implicit price deflators.

(f) Based on a 1980 estimate by Reynolds Aluminum (McMinn and Branscomb 1981). The Reynolds estimate of $\$ 0.053$ was adjusted to $1987 \$$ using GNP implicit price deflators.

(g) This value represents the total cost incurred per kilogram of anode manufactured including delivery to the service center. It reflects the credit given for hydrargillite.

determining service station markups and taxes, while the fuel cycle cost of the anode is important when attributing costs to the operation of the AT-air battery.

There is significant potential for improvements in $\mathrm{Hall}$ cell technology that will reduce electricity consumption. The baseline energy consumption assumed in this study is $13,305 \mathrm{kWh} /$ tonne.Al $(13.31 / \mathrm{kg} \cdot \mathrm{Al}$ ) (see Table 6.1). One potential energy consumption $\mathrm{Hall}$ cell retrofit currently being developed 
by the Pacific Northwest Laboratory is the use of inert anodes with titanium diboride cathodes. A second energy-reducing aluminum production technique being developed is the compact bipolar cell. These two technologies could reduce cell energy consumption to $12 \mathrm{kWh} / \mathrm{kg}$ and $9.7 \mathrm{kWh} / \mathrm{kg}$, respectively, which couid reduce the direct energy consumption for anode production by 1.31 $\mathrm{kWh} / \mathrm{kg}$ and $3.61 \mathrm{kWh} / \mathrm{kg}$. The former technology is the more likely of the two to achieve near-term application. Using carbothermic reduction for aluminum production was also examined for its potential impacts on the anode fuel cycle. If this technology were developed to its full potential anodes could be produced for roughly $11 \mathrm{kWh} / \mathrm{kg}$ (Arthur D. Little 1988).

In summary, from receipt of the raw materials through aluminum production to final anode delivery to a service center, the cost attributed to one fuel cycle while using an alloy anode with $99.99 \%$ Al base metal is estimated as $\$ 1.67$ per $\mathrm{kg}$. The corresponding attributable cost of using an unalloyed $99.5 \%$ Al anode is $\$ 1.49 / \mathrm{kg}$. The wholesale cost of these same anodes is $\$ 1.98 / \mathrm{kg}$ and $\$ 1.80 / \mathrm{kg}$, respectively. Production of the anode requires 15.1 kWh per $\mathrm{kg}$. There is potential for energy consumption associated with anode production to be reduced in the near future to $13.8 \mathrm{kWh} / \mathrm{kg} \cdot \mathrm{A}, 11.5$ $\mathrm{kWh} / \mathrm{kg} \cdot \mathrm{Al}$, or possibly $11.0 \mathrm{kWh} / \mathrm{kg} \cdot \mathrm{Al}$.

An important point to note is that currently $99.999 \%$ Al-base metal is required for anode production to suppress hydrogen production rates. Production of such metal would require an additional purification process; however, cost data on such processes was not obtainable. Therefore, the optimistic assumption of $99.99 \%$ will suffice. 


\subsection{IHE COMPLETE FUEL CYCLE}

The aluminum anode fuel cycie consists of three parts: 1) the service cycle, 2) hydrargillite reprocessing, and 3) anode manufacture. To estimate the total direct energy consumption and the total cost for the use of aluminum anodes in A1-air battery-powered vehicles, the component estimates for each of the three parts of the fuel cycle are summed to yield total direct energy consumption and cost.

Four approaches were taken to estimate the costs associated with the service cycle:

1. allowing $\$ 0.004$ per vehicle mile for service center markup, $\$ 0.125$ per kilogram of aluminum for plate installation, and $39 \%$ of the total retail cost for taxes

2. allowing $\$ 0.004$ per vehicle mile for service center markup, $\$ 0.125$ per kilogram of aluminum for plate installation, and $\$ 0.012$ per vehicle mile for taxes

3. allowing $\$ 0.125$ per kilogram of aluminum for plate instaliation, $10 \%$ of anode cost for general service markup on anodes, and $39 \%$ of the total retail cost for taxes

4. allowing $\$ 0.125$ per kilogram of aluminum for plate installation, $10 \%$ of anode cost for general service markup on anodes, and $\$ 0.012$ per vehicle mile for taxes.

In acdition, $\$ 0.0292 / \mathrm{kg} \cdot \mathrm{Al}$ for shipping the hydrargillite to the reprocessing facility must be added. Direct energy consumption attributed to the service cycle is limited to transportation of the hydrargillite to a reprocessing facility. This energy consumption is estimated as $529 \mathrm{~kJ} / \mathrm{kg} \cdot \mathrm{Al}$.

Two hydrargillite reprocessing scenarios were evaluated: 1) calcining the fydrargillite into alumina acceptable for use in the Hall process; and 2) first washing, then calcining the hydrargillite into alumina acceptable for use in the Hall process. Given the accuracy of the estimates, the difference between the two scenarios was found to be negligible. For developing the total fuel-cycle energy consumption and cost estimates, the average of the two scenario estimates was used. The values for energy consumption and hydrargillite reprocessing cost are $3.55 \times 10^{6} \mathrm{~kJ} /$ tonne.Al and $\$ 84$ per tonne of aluminum, respectiveiy. Using a conversion factor of $10,550 \mathrm{~kJ} / \mathrm{kWh}$ and 
converting to a per-kilogram basis yields an energy consumption estimate of $0.34 \mathrm{kWh} / \mathrm{kg} \cdot \mathrm{Al}$ and a cost of $\$ 0.084 / \mathrm{kg} \cdot \mathrm{Al}$.

The process of anode manufacture using the reprocessed hydrargillite is estimated to consume $14,510 \mathrm{kWh}$ and $5.95 \times 10^{6} \mathrm{~kJ}$ of direct energy per tonne of aluminum and cost $\$ 1.67 / \mathrm{kg}$. Of this $\$ 1.67$, only $\$ 0.179$ is attributed to higher purity levels and alloy enhancement. These estimates represent the incremental costs of the anode fuel cycle. The wholesale price of the anodes would be $\$ 1.98 / \mathrm{kg}$ for the alloyed $99.99 \% \mathrm{Al}$ base-metal anode and $\$ 1.80 / \mathrm{kg}$ for the $99.5 \%$ Al anode based on a $\$ 0.308 / \mathrm{kg}$ value of the hydrargillite. Based on this information, as long as base-metal purity requirements do not exceed 99.99\% aluminum, common alloying agents are used, and alloying agents do not complicate hydrargillite reprocessing, the use of alloying agents and highpurity aluminum is not a prime cost driver. There is potential for a reduction in direct energy consumption of $1.31 \mathrm{kWh} / \mathrm{kg} \cdot \mathrm{Al}$ and possibly $3.61 \mathrm{kWh} /$ $\mathrm{kg} \cdot \mathrm{A} 1$ by using inert anodes with titanium diboride cathodes and compact bipolar cells, respectively, in the anode manufacturing process. Both of these technologies are currently under development. Development of carbothermic aluminum production processes could potentially reduce total anode manufacturing energy consumption to $11 \mathrm{kWh} / \mathrm{kg}$.

Summing the direct energy consumption contributors, the total energy consumption for the fuel cycle is estimated as $14,510 \mathrm{kWh}$ and $10 \times 10^{6} \mathrm{~kJ}$ per tonne of aluminum. Using a conversion factor of $10,550 \mathrm{~kJ} / \mathrm{kWh}$, this is equivalent to $15.5 \mathrm{kWh} / \mathrm{kg} \cdot \mathrm{Al}$. There is high potential for reduction to $14.2 \mathrm{kWh} / \mathrm{kg} \cdot \mathrm{A} 1$ or possibly $11.9 \mathrm{kWh} / \mathrm{kg} \cdot \mathrm{Al}$. ELTECH Systems estimates the aluminum-to-electricity efficiency over the SAE J227a drive cycle as 3.8 $\mathrm{kWh} / \mathrm{kg}$. Using this data, the net efficiency of using an aluminum-air battery for one complete fuel cycle is calculated by dividing the net battery system output of $3.8 \mathrm{kWh} / \mathrm{kg} \cdot \mathrm{Al}$ by the direct energy consumption of the fuel cycle. This yields a net battery efficiency of $25 \%$ and $27 \%$ or $32 \%$, if developing improvements in aluminum processing come to fruition.

Table 7.1 presents a matrix of cost estimates for the complete fuel cycle. As shown in the table, to prepare final cost estimates on a dollarper-kilogram basis, an assumption must be made to relate the number of miles 
IABLE 7.1. General Fuel Cycle cost Estimates

\section{Service cycle}

1. $\$ 0.0292 / \mathrm{kg}+$

$\$ 0.004 / \mathrm{mile}+$

$\$ 0.125 / \mathrm{kg}+$

$39 \%$ on total

retail cost

2. $50.0292 / \mathrm{kg}+$

$50.016 / \mathrm{mi} \mathrm{e}+$

$50.125 / \mathrm{kg}+$

3. $50.0292 / \mathrm{kg}+$

$50.125 / \mathrm{kg}+$

$0 \%$ on anode wholesale cost +

$: 9 \%$ on total retail cost
Hydrargillite

Reprocessing

$\$ 0.084 / \mathrm{kg}$
Anode Manufacture

$\$ 1.49$ unalloyed $99.5 \%$

$\&$

$\$ 1.67$ alloyed $99.99 \%$

4. $\$ 0.0292 / \mathrm{kg}+$

$\$ 0.125 / \mathrm{kg}$

$90.012 / \mathrm{mile}+$

$10 \%$ on anode

wholesale cost

traveled to the number of kilograms of aluminum used. This aluminum-to-road mile efficiency will depend of the fina vehicle design and weight of the Alair tattery-powered vehicle. Since the vehicles have not yet been designed and aluminum-to-road mile efficiencies are likely to vary among models and intended duties, cost estimates for three different aluminum-to-road mile efficiencies were prepared. Using the battery discharge efficiency of 3.8 $\mathrm{kWh} / \mathrm{kg} \cdot \mathrm{Al}$ and assuming electricity-to-road mile efficiencies of $0.20,0.26$, and $0.31 \mathrm{kWh} / \mathrm{mile}$, the aluminum-to-road mile efficiencies of $19,14.6$, and $12.3 \mathrm{miles} / \mathrm{kg} \cdot \mathrm{Al}(30.6,23.5$, and $19.8 \mathrm{~km} / \mathrm{kg} \cdot \mathrm{Al})$ were estimated.

Applying the electricity-to-road mile efficiencies to the estimating relationships presented in the cost matrix (Table 7.1 ), estimates for $99.5 \%$ a) 7 minum anodes and alloyed $99.99 \%$ base-metal aluminum anodes were generated. The breakdowns for the $99.5 \%$ and $99.99 \%$ anodes are presented in Tables 7.2 and 7.3 , respectively. Based on the high and low estimate for each efficiency and both aluminum grades, the expected ranges for the cost of the anodes are shown in Table 7.4. 
TABLE 7.2. Anode Cost Estimate for Alloy with $99.99 \%$ Aluminum Base Metal

$19 \mathrm{mile} / \mathrm{kg}(30.6 \mathrm{~km} / \mathrm{kg})$

1. $\$ 0.084 / \mathrm{kg}+$

$\$ 0.0292 / \mathrm{kg}+$

(19 mile/kg) $(\$ 0.004 / m i)+$ $\$ 0.125 / \mathrm{kg}+$

$\$ 0.314 / \mathrm{kg}$ * $39 \%+$

$(\$ 1.98 / \mathrm{kg})(0.39)+$

$\$ 1.67 / \mathrm{kg}$

$\$ 2.88 / \mathrm{kg}$

2. $\$ 0.084 / \mathrm{kg}+$

$\$ 0.0292 / \mathrm{kg}+$

$(19 \mathrm{mile/kg})(\$ 0.016 / \mathrm{mi})+$ $\$ 0.125 / \mathrm{kg}+$

$\$ 1.67 / \mathrm{kg}$

$\$ 2.21 / \mathrm{kg}$

3. $\$ 0.084 / \mathrm{kg}+$

$\$ 0.0292 / \mathrm{kg}+$

$\$ 0.125 / \mathrm{kg}+$

$(0.10)(\$ 1.98 / \mathrm{kg})+$

$\$ 0.436$ * $39 \%+$

$(\$ 1.98 / \mathrm{kg})(0.39)+$

$\$ 1.67 / \mathrm{kg}$

$\$ 3.05 / \mathrm{kg}$

4. $\$ 0.084 / \mathrm{kg}+$

$\$ 0.0292 / \mathrm{kg}+$

(19 mi $(\mathrm{e} / \mathrm{kg})(\$ 0.012 / \mathrm{mi})+$ $50.125 / \mathrm{kg}+$

$(0.10)(\$ 1.98 / \mathrm{kg})+$

$\$ 1.67 / \mathrm{kg}$

$\$ 2.33 / \mathrm{kg}$
$14.6 \mathrm{mi}(\mathrm{e} / \mathrm{kg}(23.5 \mathrm{~km} / \mathrm{kg})$

$\$ 0.084 / \mathrm{kg}+$

$\$ 0.0292 / \mathrm{kg}+$

$(14.6 \mathrm{mi}(\mathrm{e} / \mathrm{kg})(50.004 / \mathrm{mi})+$ $\$ 0.125 / \mathrm{kg}+$

$\$ 0.297 / \mathrm{kg} * 39 \%+$

$(\$ 1.98 / \mathrm{kg})(0.39)+$

$\$ 1.67 / \mathrm{kg}$

$\$ 2.86 / \mathrm{kg}$

$\$ 0.084 / \mathrm{kg}+$

$\$ 0.0292 / \mathrm{kg}+$

$(14.6 \mathrm{mile} / \mathrm{kg})(\$ 0.016 / \mathrm{mi})+$

$\$ 0.125 / \mathrm{kg}+$

$\$ 1.67 / \mathrm{kg}$

$\$ 2.14 / \mathrm{kg}$

$\$ 0.084 / \mathrm{kg}+$

$\$ 0.0292 / \mathrm{kg}+$

$\$ 0.125 / \mathrm{kg}+$

$(0.10)(\$ 1.98 / \mathrm{kg})+$

$50.436 * 39 \%+$

$(\$ 1.98 / \mathrm{kg})(0.39)+$

$\$ 1.67 / \mathrm{kg}$

$\$ 3.05 / \mathrm{kg}$

$\$ 0.084 / \mathrm{kg}+$

$\$ 0.0292 / \mathrm{kg}+$

$(14.6 \mathrm{mile} / \mathrm{kg})(\$ 0.012 / \mathrm{mi})+$

$\$ 0.125 / \mathrm{kg}+$

$(0.10)(\$ 1.98 / \mathrm{kg})+$

$\$ 1.67 / \mathrm{kg}$

$\$ 2.28 / \mathrm{kg}$
$12.3 \mathrm{mile} / \mathrm{kg}(19.8 \mathrm{~km} / \mathrm{kg})$

$\$ 0.084 / \mathrm{kg}+$

$\$ 0.0292 / \mathrm{kg}+$

$(12.3 \mathrm{mile} / \mathrm{kg})(\$ 0.004 / \mathrm{mi})+$

$\$ 0.125 / \mathrm{kg}+$

$50.287 / \mathrm{kg} * 39 \%+$

$(51.98 / \mathrm{kg})(0.39)+$

$\$ 1.67 / \mathrm{kg}$

$52.84 / \mathrm{kg}$

$\$ 0.084 / \mathrm{kg}+$

$\$ 0.0292 / \mathrm{kg}+$

$(12.3 \mathrm{mile} / \mathrm{kg})(\$ 0.016 / \mathrm{mi})+$

$\$ 0.125 / \mathrm{kg}+$

$\$ 1.67 / \mathrm{kg}$

$\$ 2.11 / \mathrm{kg}$

$\$ 0.034 / \mathrm{kg}+$

$\$ 0.0292 / \mathrm{kg}+$

$\$ 0.125 / \mathrm{kg}+$

$(0.10)(\$ 1.98 / \mathrm{kg})+$

$\$ 0.436 * 39 \%+$

$(\$ 1.98 / \mathrm{kg})(0.39)+$

$\$ 1.67 / \mathrm{kg}$

$\$ 3.05 / \mathrm{kg}$

$50.084 / \mathrm{kg}+$

$\$ 0.0292 / \mathrm{kg}+$

$(12.3 \mathrm{mile} / \mathrm{kg})(\$ 0.012 / \mathrm{mi})+$

$\$ 0.125 / \mathrm{kg}+$

$(0.10)(\$ 1.98 / \mathrm{kg})+$

$\$ 1.67 / \mathrm{kg}$

$\$ 2.25 / \mathrm{kg}$ 


\section{IABLE 7.3. Anode Cost Estimate for $99.5 \%$ Aluminum}

$15 \mathrm{mile} / \mathrm{kg}(30.6 \mathrm{~km} / \mathrm{kg})$

1. $\$ .084 / \mathrm{kg}+$

$\$ \mathrm{C} .0292 / \mathrm{kg}+$

$(19 \mathrm{mile} / \mathrm{kg})(\$ 0.004 / \mathrm{mi})+$

$\$ 0.125 / \mathrm{kg}+$

$\$ 0.314 / \mathrm{kg} * 39 \%+$

$(\$ 1.80 / \mathrm{kg})(0.39)+$

$\$ 1.49 / \mathrm{kg}$

$\$ 2.63 / \mathrm{kg}$

2. $\$ 0.084 / \mathrm{kg}+$

$\$ 0.0292 / \mathrm{kg}+$

$(19$ mile/kg)(\$0.016/mi $)+$

$\$ 0.125 / \mathrm{kg}+$

$\$ 1.49 / \mathrm{kg}$

$\$ 2.03 / \mathrm{kg}$

3. $\$ 0.084 / \mathrm{kg}+$

$\$ 0.0292 / \mathrm{kg}+$

$\$ 0.125 / \mathrm{kg}+$

$(0.10)(\$ 1.80 / \mathrm{kg})+$

$\$ 0.416 * 39 \%+$

$(\$ 1.80 / \mathrm{kg})(0.39)+$

$\$ 1.49 / \mathrm{kg}$

$\$ 2.77 / \mathrm{kg}$

4. $\$ 0084 / \mathrm{kg}+$

so $0292 / \mathrm{kg}+$

(1) mile/kg)(\$0.012/mi) +

\$0 $125 / \mathrm{kg}+$

(0 10) $(\$ 1.80 / \mathrm{kg})+$

$\$ 149 / \mathrm{kg}$

$5214 / \mathrm{kg}$
$14.6 \mathrm{mile} / \mathrm{kg}(23.5 \mathrm{~km} / \mathrm{kg})$

$\$ 0.084 / \mathrm{kg}+$

$\$ 0.0292 / \mathrm{kg}+$

$(14.6 \mathrm{mi}(\mathrm{e} / \mathrm{kg})(\$ 0.004 / \mathrm{mi})+$

$\$ 0.125 / \mathrm{kg}+$

$\$ 0.297 / \mathrm{kg} * 39 \%+$

$(\$ 1.80 / \mathrm{kg})(0.39)+$

$\$ 9.49 / \mathrm{kg}$

$\$ 2.60 / \mathrm{kg}$

$\$ 0.084 / \mathrm{kg}+$

$\$ 0.0292 / \mathrm{kg}+$

(14.6 mile/kg)(\$0.016/mi ) +

$\$ 0.125 / \mathrm{kg}+$

$\$ 1.49 / \mathrm{kg}$

$\$ 1.96 / \mathrm{kg}$

$\$ 0.084 / \mathrm{kg}+$

$\$ 0.0292 / \mathrm{kg}+$

$\$ 0.125 / \mathrm{kg}+$

$(0.10)(\$ 1.80 / \mathrm{kg})+$

$\$ 0.416 * 39 \%+$

$(\$ 1.80 / \mathrm{kg})(0.39)+$

$\$ 1.49 / \mathrm{kg}$

$\$ 2.77 / \mathrm{kg}$

$\$ 0.084 / \mathrm{kg}+$

$\$ 0.0292 / \mathrm{kg}+$

$(14.6 \mathrm{mile} / \mathrm{kg})(\$ 0.012 / \mathrm{mi})+$

$\$ 0.125 / \mathrm{kg}+$

$(0.10)(\$ 1.80 / \mathrm{kg})+$

$\$ 1.49 / \mathrm{kg}$

$\$ 2.08 / \mathrm{kg}$
$12.3 \mathrm{mi} \mathrm{le} / \mathrm{kg}(19.8 \mathrm{~km} / \mathrm{kg})$

$\$ 0.084 / \mathrm{kg}+$

$\$ 0.0292 / \mathrm{kg}+$

$(12.3 \mathrm{mile} / \mathrm{kg})(\$ 0.004 / \mathrm{mi})+$ $\$ 0.125 / \mathrm{kg}+$

$\$ 0.287 / \mathrm{kg} * 3 \% \%+$

$(\$ 1.80 / \mathrm{kg})(0.39)+$

$\$ 1.49 / \mathrm{kg}$

$\$ 2.59 / \mathrm{kg}$

$\$ 0.084 / \mathrm{kg}+$

$\$ 0.0292 / \mathrm{kg}+$

$(12.3 \mathrm{mile} / \mathrm{kg})(50.016 / \mathrm{mi})+$ $\$ 0.125 / \mathrm{kg}+$

$\$ 1.49 / \mathrm{kg}$

$\$ 1.93 / \mathrm{kg}$

$\$ 0.084 / \mathrm{kg}+$

$\$ 0.0292 / \mathrm{kg}+$

$\$ 0.125 / \mathrm{kg}+$

$(0.10)(\$ 1.80 / \mathrm{kg})+$

$50.416 * 39 \%+$

$(\$ 1.80 / \mathrm{kg})(0.39)+$

$51.49 / \mathrm{kg}$

$\$ 2.77 / \mathrm{kg}$

$\$ 0.084 / \mathrm{kg}+$

$\$ 0.0292 / \mathrm{kg}+$

$(12.3 \mathrm{mile} / \mathrm{kg})(50.012 / \mathrm{mi})+$

$\$ 0.125 / \mathrm{kg}+$

$(0.10)(\$ 1.80 / \mathrm{kg})+$

$\$ 1.49 / \mathrm{kg}$

$\$ 2.06 / \mathrm{kg}$ 


\section{IABLE 7.4. Range of Anode Cost Estimates}

\begin{tabular}{|c|c|c|}
\hline Mi $\rceil e s / \mathrm{kg}(\mathrm{km} / \mathrm{kg})$ & Alloyed $99.99 \%$ & Unalloyed $99.5 \%$ \\
\hline$(30.6)$ & $\$ 2.21-\$ 3.05 / \mathrm{kg}$ & $\$ 2.77 / \mathrm{kg}$ \\
\hline $44.6(23.5)$ & $\$ 2.14-\$ 3.05 / \mathrm{kg}$ & $\$ 1.96-\$ 2.77 / \mathrm{kg}$ \\
\hline $12.3(19.8)$ & $\$ 2.11-\$ 3.05 / \mathrm{kg}$ & $\$ 1.93$ \\
\hline
\end{tabular}




\subsection{REFERENCES}

Brown, D. R., et al. 1987. Assessment Methodology for Thermal Energy Storage Evaluation. PNL-6372, Pacific Northwest Laboratory, Richland, Washington.

Cooper, J. 1980. Estimates of the Cost and Energy Consumption of Aluminum Air Electric Vehicles. UCRL-84445, Lawrence Livermore Laboratory, Livermore, California.

Cooper, J. 1984. Estimate of the Consumer Cost of Aluminum Fuel for Electric Vehicles. UCRL-90468, Lawrence Livermore Laboratory, Livermore, California.

Doane, J. W. , et al. 1976. The Cost of Energy from Utility-Owned Solar Elec.ric systems. ERDA/JPL-1012-76/3, Jet Propulsion Laboratory, Pasadena, California.

ELTECH Systems Corporation. 1987. Aluminum-Air Battery Development: Final Report. Contract 1806205, ELTECH Systems Corporation, Fairport Harbor, Ohio.

Eneryy Information Administration (EIA). 1987a. Annual Energy Outlook 1986. DOE/IIA-0383(86), U.S. Department of Energy, Washington, D.C.

Energy Information Administration (EIA). 1987b. Annual Energy Review 1986. DOE/I.IA-0384(86), U.S. Department of Energy, Washington, D.C.

Hardy', K. 1985. Advanced Vehicle Systems Assessment: Executive Summary. DOE/CS-54209-22, Jet Propulsion Laboratory, Pasadena, California.

Hudson, C. L., and E. S. Putnam. 1980. Preliminary Eneray Use and Economic Analy sis of the Aluminum-Air Battery for Automotive Propulsion. R7908, Interplan Corporation, Santa Barbara, California.

Kramer, D. A., and F. A. Peters. 1983. Cost Estimate of the Bayer Process for Froducing Alumina--Based on 1982 Equipment Prices. IC-8958, U.S. Department of the Interior, Pittsburgh, Pennsylvania.

Light Metal Age. April 1988. "International Primary A7uminum Production." Light Metal Age $46(3,4)$, p. 45.

Littie, A. D. 1988. Iechno-Economic: Assessment of a Carbo Thermic Alumina Reduction. DOE/ID-10208, U.S. Department of Energy, Washington, D.C.

Lussky, E. W. 1980. Experience with Operation of the ALCOA Fluid Flash

Calciner. Aluminum Company of America, Pittsburgh, Pennsylvania.

McMinn, C. J., and J. A. Branscomb. 1981. Production of Anodes for Aluminum-Air Power Cells Directly from Hall Cell Metal. UCRL-15354, Lawrence Livermore Laboratory, Livermore, California. 
Sen, R. K., et al. May 1988. Metal-Air Battery Assessment. PNL-6475, Pacific Northwest Laboratory, Richland, Washington.

Shen, S. Y. 1981. Energy and Materials Flows in the Production of Primary Aluminum. ANL/CNSV-21, Argonne National Laboratory, Argonne, 111 inois.

U.S. Department of Commerce. 1977. Business Statistics. U.S. Department of Commerce, Washington, D.C.

U.S. Department of Commerce. 1978. Survey of Current Business. U.S. Department of Commerce, Washington, D.C.

U.S. Department of Commerce. 1979. Survey of Current Business. U.S. Department of Commerce, Washington, D.C.

U.S. Department of Commerce. 1980. Survey of Current Business. U.S. Department of Conmerce, Washington, D.C.

U.S. Department of Commerce. 1981. Survey of Current Business. U.S. Department of Commerce, Washington, D.C.

U.S. Department of Commerce. 1982, Survey of Current Business. U.S. Department of Commerce, Washington, D.C.

U.S. Department of Commerce. 1983. Survey of Current Business. U.S. Department of Commerce, Washington, D.C.

U.S. Department of Commerce. 1985. Survey of Current Business. U.S. Department of Commerce, Washington, D.C.

U.S. Department of Commerce. 1986. Survey of Current Business. U.S. Department of Commerce, Washington, D.C.

U.S. Department of Commerce. 1987. Survey of Current Business. U.S. Department of Commerce, Washington, D.C. 


\section{APPENDIX A}

ECONOMIC ANALYSIS METHODOLOGY FOR

THE DETERMINATION OF HYDRARGILLITE REPROCESSING COSTS 
APPENDIX A

\section{ECONOMIC ANALYSIS METHDDOLOGY FOR THE DETERMINATION OF HYDRARGILLITE REPROCESSING COSTS}

The economic methodology used for the determination of hydrargillite reprocessing costs is based on a real-1987-dollar analysis, as opposed to a nominal-dollar analysis. The basic formula for calculating the unit cost per ton of alumina produced from reprocessing is as follows:

$$
(P C C)\left(F C R_{p}\right)+(W C)\left(F C R_{w C}\right)+O C=R
$$

wher $3 P C C=$ the plant capital cost per ton of alumina capacity

$F C R_{p}=$ the annualized fixed charge rate for plant capital

$W C=$ the working capital per ton of alumina capacity

$F C R_{W C}=$ the annualized fixed charge rate for working capita?

$O C=$ the annual operating cost per ton of alumina produced

$\mathrm{R} \quad=$ the reprocessing cost per ton of alumina produced.

The values for $P C C, W C, O C$, and $R$ depend on the particular plant design. The determination of these values is discussed in Appendix $B$. The determination of the FCRs is discussed in this appendix.

The fixed charge rate is the factor which, when multiplied by the present value of the capital investment, determines the contribution of the capi1.al investment toward the annuarized plant cost. The annual plant cost divicied by plant capacity yields the annualized cost per unit of product produced. The formula for the FCR is as follows:

$$
\operatorname{CRF}((1-\mathrm{T}(\mathrm{DPF})-\mathrm{ITC}) /(1-\tau))+\beta
$$

where $\mathrm{CRF}=$ the capital recovery factor

$$
\tau=\text { the tax rate }
$$

DPF $=$ the real depreciation factor 


$$
\begin{aligned}
\text { ITC } & =\text { the investment tax credits } \\
\beta & =\text { the additional tax rate and insurance (Doane et al. 1976). }
\end{aligned}
$$

The 1986 Tax Reform Act eliminated investment tax credits; therefore, ITC is equal to zero. The term is included in the formula because, at some future time, investment tax credits may be reintroduced. The combined state and federal tax rate $(\tau)$ is assumed to be 39.1 percent (Brown et a1. 1987). Additional taxes and insurance $(\beta)$ are estimated as 2 percent (Doane et al. 1976, Brown et al. 1987). The FCR equation incorporates an implicit assumption that taxes and insurance $(\beta)$ are paid with before-tax dollars, while the return on capital is paid with after-tax dollars. The CRF is calculated as follows:

$$
k /\left(1-(1+k)^{-N}\right)
$$

where $k$ = the real discount rate $\mathrm{N}=$ the project life (Doane et al, 1976).

The discount rate used in the estimates developed in this study is 6.0 percent, which is the real after-tax discount rate for general industry (Brown et al. 1987). A project life of 21 years was used. This is the average economic life of equipment used in the nonferrous metai industry (Brown et a1. 1987). Making these substitutions into the CRF equation yields a CRF of 0.085 . The depreciation factor (DPF) represents the present vaiue of future depreciation credits. It is determined by summing the deflated nominal depreciation credits established by IRS for each depreciable project year. Determination of the DPF requires the determination of the appropriate IRS depreciation schedule and an inflation rate.

The estimated economic life for equipment used in the nonferrous metals industry is 21 years (Brown et a1. 19B7). This corresponds to an IRS asset depreciation range (ADR) class life of fourteen years. For projects with ADR class lives of more than ten years but less than sixteen years, a modified ACRS depreciation schedule of seven years is applicable. This depreciation schedule is presented in Table A.l. The depreciation schedule is in nominal 
dollars at initial investment time; therefore, the values in the schedule must be deflated to allow for the devaluation of the dollar between the init al investment time and the tax year of recovery. This deflating was perfurmed using an inflation rate of 3.1 percent (Brown et a1. 1987). Table: A.2 presents the deflated depreciation schedule. The total presented in Tible A.2 is the DPF.

TABLE A.1. Modified Seven-Year ACRS Depreciation Table for 1987 and Beyond

\begin{tabular}{|c|c|}
\hline Year & Depreciation Percentage \\
\hline $\begin{array}{l}1 \\
2 \\
3 \\
4 \\
5 \\
6 \\
7\end{array}$ & $\begin{array}{l}14 \\
25 \\
17 \\
13 \\
11 \\
10 \\
10\end{array}$ \\
\hline Sum & 100 \\
\hline
\end{tabular}

TABLE A.2. Discounted and Modified Seven-Year ACRS Depreciation Table for 1987 and Beyond

\begin{tabular}{|c|c|}
\hline Year & Depreciation Percentage \\
\hline $\begin{array}{l}1 \\
2 \\
3 \\
4 \\
5 \\
6 \\
7\end{array}$ & $\begin{array}{r}14.0 \\
24.2 \\
16.0 \\
11.9 \\
9.7 \\
8.6 \\
8.3\end{array}$ \\
\hline Sum & 92.7 \\
\hline
\end{tabular}

Applying the FCR methodology and assumptions outlined above, the fixed charge rates for plant capital $\left(F C R_{p}\right.$ ) and working capital (FCR wC $_{\text {) can be }}$ determined as shown below: 


$$
F C R_{p}=0.085((1-0.391 \star 0.9275-0) /(1-0.391)+0.02=0.11 .
$$

When calculating $F C R_{w C}$, the variable DPF is zero because working capital is a non-depreciable investment. In addition, working capital is fully recovered in nominal dollars at the end of the project 1 ife; therefore, the raw FCR calculated from the general equation must be discounted over the project life. This yields an effective $F_{C R}$ as follows:

$$
\begin{aligned}
\mathrm{FCR}_{\mathrm{WC}}= & \left(0 . 0 8 5 \left(\left(1-0.391 \star_{0}-0\right) /\right.\right. \\
& (1-0.391)+0.02)\left(1-\left(1 / 1.06^{21}\right)\right)=0.11 .
\end{aligned}
$$


APPENDIX B

CAPITAL AND OPERATING COST ESTIMATES FOR

CALCINING AND WASHING/CALCINING FACILITIES FOR HYDRARGILLITE REPROCESSING 
APPENDIX B

CAPITAL AND OPERATING COST ESTIMATES FOR

CALCINING AND WASHING/CALCINING FACILITIES FOR HYDRARGILLITE REPROCESSING

These capital cost estimates are for a hydrargillite calcining facility and a hydrargillite washing/calcining facility that have production capacities of 1 million (English) tons of alumina per year. The estimates are in 1987 clollars. A11 costs are based on data presented in Cost Estimate of the Bayer Process for Producing Alumina-Based on 1982 Equipment Prices (Kramer and Peters 1983). The equipment costs in this report were updated to 1987 dollar's using the Marshall \& Swift equipment cost indices.

able B.1 presents a breakdown of the capital cost estimate for the calcining facility. Equipment costs are divided into two sections: one for equiprent cost data gathered on an uninstalled basis and the other for equipment cost data gathered on an installed basis. Equipment cost data that are on an uninstalled basis (the feeders) have additional costs allocated to them cor installation iabor, foundations, buildings, structures, instrumentation, electrical subsystems, piping, painting, and a miscellaneous category. Equipment cost data gathered on an installed basis (silos and caiciners) are added to the sum of the uninstalled equipment costs and their installation and siupport costs. This yields a total direct cost for the plant of $\$ 36,11) 4,700$. 
TABLE B.I. Capital Investment Cost Estimate for a Calcining Facility for Hydrargilitite Reprocessing

\begin{tabular}{|c|c|c|c|}
\hline Uninstalled Equipment Items & EQUIPMENT & LABOR & TOTAL \\
\hline Feeders & 85,300 & 12,800 & 98,100 \\
\hline TOTAL & 85,300 & 12,800 & 98,100 \\
\hline
\end{tabular}

Total equipment cost $x$ factor indicated:

Foundations, 0.321

Buildings, 0.002

31,500

Structures, 0.05

Instrumentation, 0.15

Electrical, 0.062

Piping, 0.40

Painting, 0.050

Miscellaneous, 0.10 (Kramer and Peters 1983)

200

4,900

14,700

6,100

39,200

4,900

Subtotal

9,800

111,300

Installed Equipment

Calciners

Silos

$\$ 17,825,600(a)$

$18,069,700$

Subtotal

$35,895,300$

TOTAL DIRECT COST

$36,104,700$

Field indirect, $10.0 \%$ of total direct cost

$\underline{3,610,500}$

Total construction cost

$39,715,200$

Engineering, $10.0 \%$ of total construction cost

$3,971,500$

Administration and overhead, $5.0 \%$ of total

construction cost

$1,985,800$

Subtota?

$45,672,500$

Contingency, $15.0 \%$ of above subtotal

$6,850,900$

Subtota]

$52,523,400$

(a) The calcining equipment, which includes washing equipment, is estimated to cost $\$ 20,028,800$. Robert A. Rand of Alcoa, in a personal communication on June 7,1988 , roughly estimated that the washing equipment contributed $10 \%$ to $12 \%$ of the total capital cost. Based on this information, $11 \%$ was deducted from the calcining equipment estimate of $\$ 20,028,800$ to exclude unnecessary washing equipment. 


\section{TABLE B.1. (contd)}

i.ontractor's fee, $5.0 \%$ of above subtotal

$\underline{2,626,200}$

Subtotal

$55,149,600$

Plant facilities (10\%)

Plant utilities (12\%)

$5,515,000$

$6,618,000$

Total Plant Cost

$67,282,600$

FIXED CAPITAL COST (assuming overnight construction period) (i.e., no interest or escalation during construction)

Wrking Capital:

Raw materials and supplies

Product and in-process inventory

Accounts receivable

Available cash

$\mathrm{B}, 749,400$

$10,928,900$

$10,928,900$

$\underline{10,793,800}$

WIRKING CAPITAL COST

$41,401,000$

Capitalized startup costs

672,800

Subtotal

$\underline{42,073,800}$

TJTAL CAPITAL COST

$109,356,400$

=ield indirects, which are estimated as $10 \%$ of the direct cost, cover field supervisors, temporary construction facilities, rental construction equipinent, and payroll overheads. Project engineering is estimated as $10 \%$ of the tutal construction cost. An additional $5 \%$ of the total construction cost is adfed to cover administration and overheads. To the subtotal of all these costs, a 15\% contingency is added. Subtotaling again, an estimated contractor's fee of $5 \%$ is added. The total of all these costs, pius $10 \%$ and $12 \%$ for plant facilities and utilities, respectively, yields the total plant cost. Capitalized startup costs are estimated as one percent of the total plant cost (Kramer and Peters 1983). The grand total represents the depreciable investment.

In addition to these costs, a working capital allowance is estimated to include the value of the following four items: 1) raw materials and 
supp 1ies for 30 days, 2) product and in-process inventory (total operating cost for 30 days), 3) accounts receivable (total operating cost for 30 days), and 4) available cash (direct expenses for 30 days) (Kramer and Peters 1983). Working capital is a non-depreciable investment that is recovered at the end of the project life.

The cost to reprocess hydrargillite, not the value of the hydrargillite, has been the focus of this study. This approach was taken because the reprocessing costs are more certain than the market price, which would be affected by numerous factors external to the actual reprocessing cost. For estimating the operating costs associated with the anode, the reprocessing cost is the most relevant cost, because if the market value of the hydrargillite is temporarily high, the higher value of the hydrargillite at discharge would be largely offset by the higher cost of replacement anodes. Therefore, the consumer would mainiy be affected by the actual reprocessing costs and not the market value of hydrargillite. The value of hydrargillite is needed, however, to estimate the appropriate amount of working capital required by the reprocessing facility.

To determine the value of hydrargillite for use in the working capital estimate only, the value of hydrargillite is assumed to be the current cost of alumina less hydrargillite reprocessing costs. A current cost of alumina of $\$ 145$ per ton ( $\$ 160$ per tonne; Arthur D. Little 1988) was used. Working capital is estimated as $\$ 6,403,500$ (i.e., $\$ 0$ for raw materials; $\$ 2,179,500$ for product and in-process inventory; $\$ 2,179,500$ for accounts receivable; and $\$ 2,044,500$ for available cash), plus the following:

1. the value of a 30-day raw material supply of hydrargillite

2. the value of a 30-day suppiy of hydrargillite for in-process inventory

3. the value of a 30-day suppiy of hydrargillite for accounts receivable

4. the value of a 30-day supply of hydrargillite for direct expenses. This totals to $\$ 6,403,500$ plus the value of a 120 -day supply of hydrargillite. Allowing " $R$ " to equal the reprocessing cost, the value of hydrargillite is $\$(145-R)$ per ton of alumina produced. This yields a working capital estimate of $\$ 6.4035+\$(145-R)(120 / 365)$ per ton of alumina produced per year. 
3ased on the economic methodology presented in Appendix A, the reprozessing cost, $R$, is equal to the following:

(plant capital cost per ton of annual alumina production)

(fixed charge rate) +

(working capital per ton of annual alumina production)

(fixed charge rate) +

annual operating cost per ton of alumina production.

Substituting the plant capital cost of $\$ 67.96 /$ annual ton, a fixed charge rate of 0.11 , working capital of $\$ 6.4035$ /annual - ton $+\$(145-R)(120 / 365) /$ annual-ton, a working capital fixed charge rate of 0.11 , and adding the operating cost of $\$ 26.52 /$ ton, the equation yields a value for "R" of $\$ 38.55$ per ton of alumina produced (\$42.50 per (metric) tonne of alumina produced). Using this value of " $R$ ", working capital is estimated as $\$ 41,401,000$ (see Table B.1).

A breakdown of the operating costs excluding the purchase cost of the hydrargillite is presented in Table B.2. The price of fossil fuel is the dominating utility cost. The amount of fossil fuel consumed is $3.11 \times 10^{6}$ Btu/ton.Al $\left(3.43 \times 10^{6} \mathrm{~kJ} /\right.$ tonne.Ai) (see Table 5.7 ) which is equivalent to $5.99 \times 10^{6} \mathrm{Btu} / \mathrm{ton} \cdot \mathrm{alumina}$. Based on a primary energy cost of $\$ 3.26$ per MBtu (1987 dollars) (EIA 1987a) and an annual production level of $1 \times 10^{6}$ tons of alumina, the annual energy cost is $\$ 19,527,400$. Direct labor is estimated at $\$ 15$ per hour for 5 workers per shift and 3 shifts per day. Direct labor supervision is $15 \%$ of direct labor. Plant maintenance labor and materials are each estimated as $2.264 \%$ of the total plant cost. Maintenance supervision is $20 \%$ of maintenance labor. Payroll overhead is $35 \%$ of the operating payrc11. Operating supplies are estimated as $10 \%$ of plant maintenance. Finally, indirects are estimated as $40 \%$ of the direct labor and maintenance (Kramer and Peters 1983). The total annual operating cost is $\$ 26,517,500$. 
TABLE B.2. Total Annual Operating Cost for a Calcining Facility for the Reprocessing of Hydrargillite

DIRECT COST :

Utilities:

Fossil Fuel $\$ 19,527,400$

Direct Labor:

Labor $15 / \mathrm{hr}$

Supervision (15\% of labor)

657,600

98,600

756,200

Plant Maintenance:

Labor (2.264\% of total plant cost)

Supervision (20\% of maintenance 1 abor)

Materials (2.264\% of total plant cost)

$1,523,300$

304,700

$1,523,300$

Total

$3,351,300$

Payro11 overhead, $35 \%$ of above payro11

904,500

Operating supplies, $10 \%$ of plant maintenance

335,100

$1,239,600$

TOTAL DIRECT

$24,874,500$

INOIRECT COST ( $40 \%$ of direct labor and maintenance)

$1,643,000$

TOTAL ANNUAL OPERATING COST

$26,517,500$

TOTAL ANNUAL OPERATING COST, $\$ /$ ton·AI

51.05

TOTAL ANNUAL OPERATING COST, $\$$ /ton-alumina

26.52

TOTAL ANNUAL OPERATING COST, \$/ton hydrargi11ite

15.52

TOTAL ANNUAL OPERATING COST, $\$ /$ tonne $\cdot A 1$

56.29

TOTAL ANNUAL OPERATING COST, \$/tonne-alumina

29.23

TOTAL ANNUAL OPERATING COST, \$/tonne hydrargillite

17.11

B. 6 
Table B.3 presents a breakdown of the capital cost estimate for a washing/calcining facility. Equipment costs are broken into two sections, one for which the equipment cost data were gathered on an uninstalled basis and the other for equipment cost data gathered on an uninstalled basis. Equipment cost data that are on an uninstalled basis (the feeders) have additional costs allocated to them for installation labor, foundations, buildings, structures, instrumentation, electrical subsystems, piping, painting, and a miscellaneous category. Equipment cost data gathered on an installed basis, silos and calciners, are added to the sum of the uninstalled equipment costs and their installation and support costs. This yields a total direct cost for the plant of $\$ 38,307,900$.

Working capital is estimated as $\$ 6,811,600$ (i.e., $\$ 0$ for raw materials; $\$ 2,317,800$ for product and in-process inventory; $\$ 2,317,800$ for accounts receivable; and $\$ 2,176,000$ for available cash), plus the following:

1. the value of a 30-day raw material supply of hydrargillite

2. the value of a 30-day supply of hydrargillite for in-process inventory

3. the value of a 30-day supply of hydrargillite for accounts receivable

4. the value of a 30-day supply of hydrargillite for direct expenses. This totals to $\$ 6,811,600$ plus the value of a 120 -day supply of hydrargillite. Allowing " $R$ " to equal the reprocessing cost, the value of hydrargillite is $\$(145-R)$ per ton of alumina produced. This yields a working capital estimate of $\$ 6.8116+\$(145-R)(120 / 365)$ per ton of a Tumina produced per year.

Based on the economic methodology presented in Appendix $A$, the reprocessing cost, $R$, is equal to the following:

(plant capital cost per ton of annual alumina production) (fixed charge rate) + (working capital per ton of annual alumina production) (capital recovery factor) + annual operating cost per ton of alumina production. 
TABLE B.3. Capita] Investment Cost Estimate for a Washing/Calcining Facility for Hydrargillite Reprocessing

\begin{tabular}{|c|c|c|}
\hline Uninstalled Equipment Items & LABOR & TOTAL \\
\hline 85,300 & 12,800 & 98,100 \\
\hline 85,300 & 12,800 & 98,100 \\
\hline $\begin{array}{l}\text { Total equipment cost } \times \text { factor indicated: } \\
\text { Foundations, } 0.321 \\
\text { Buildings, } 0.002 \\
\text { Structures, } 0.05 \\
\text { Instrumentation, } 0.15 \\
\text { Electrical, } 0.062 \\
\text { Piping, } 0.40 \\
\text { Painting, } 0.050 \\
\text { Miscellaneous, } 0.10 \text { (Kramer and Peters 1983) }\end{array}$ & & $\begin{array}{r}31,500 \\
200 \\
4,900 \\
14,700 \\
6,100 \\
39,200 \\
4,900 \\
9,800 \\
\end{array}$ \\
\hline Subtotal & & 111,300 \\
\hline $\begin{array}{l}\text { Installed Equipment } \\
\text { Calciners } \\
\text { Silos }\end{array}$ & & $\begin{array}{r}\$ 20,028,800 \\
18,069,700 \\
\end{array}$ \\
\hline Subtotal & & $38,098,500$ \\
\hline TOTAL DIRECT COST & & $38,307,900$ \\
\hline Field indirect, $10.0 \%$ of total direct cost & & $3,830,800$ \\
\hline Total construction cost & & $42,138,700$ \\
\hline $\begin{array}{l}\text { Engineering, } 10.0 \% \text { of total construction cost } \\
\text { Administration and overhead, } 5.0 \% \text { of total } \\
\text { construction cost } \\
\text { Subtotal }\end{array}$ & & $\begin{array}{r}4,213,900 \\
2,106,900 \\
48,459,500\end{array}$ \\
\hline Contingency, $15.0 \%$ of above subtotal & & $7,268,900$ \\
\hline Subtotal & & $55,728,400$ \\
\hline Contractor's fee, $5.0 \%$ of above subtotal & & $2,786,400$ \\
\hline Subtotal & & $58,514,800$ \\
\hline
\end{tabular}


TABLE B.3. (contd)
Plant facilities (10\%)
Plant utilities (12\%)
$5,851,500$
$7,021,800$
Total Plant Cost
$71,388,100$
FIXED CAPITAL COST (assuming one-year construction period) (i.e., no interest or escalation during construction)
Wrking Capital:
Raw materials and supplies
Product and in-process inventory
Accounts receivable
Available cash
$71,388,100$
WJRKING CAPITAL COST
Capitalized startup costs
$9,604,700$
$11,922,500$
$11,922,500$
$\underline{11,780,600}$
$45,230,300$
Subtotal
713,900
$45,944,200$
TJTAL CAPITAL COST
$117,332,300$

Substituting the plant capital cost of $\$ 72.102 /$ annual-ton, a plant capital fixed charge rate of 0.11 , working capital of $\$ 6.8116 /$ annual ton $+\$(145$ R) $(12 J / 365)$ /annual-ton, a working capital fixed charge rate of 0.11 , and an operating cost of $\$ 28.20 /$ ton, the equation yields a value for "R" of $\$ 40.65$ per ton of alumina produced ( $\$ 44.83$ per tonne of aiumina produced). Using this value of "R", working capital is estimated as $\$ 45,230,300$ (see Table B.3).

4 breakdown of the operating costs, excluding the purchase cost of the hydrargitlite, is presented in Table B.4. The price of fossil fuel is the dominating utility cost. The amount of fossil fuel consumed is $3.32 \times 10^{6}$ $B t u /$ ton.Al $\left(3.66 \times 10^{6} \mathrm{~kJ} /\right.$ tonne.Al) (see Table 4.7$)$, which is equivalent to $6.39 \times 10^{6} \mathrm{Btu} /$ ton-alumina. Based on a primary energy cost of $\$ 3.26$ per MBtu (1987 dol1ars) (EIA 1987a) and an annual production level of $1 \times 10^{6}$ tons of alumina, the annual energy cost is $\$ 20,831,400$. Direct labor is estimated at $\$ 15$ per hour for 5 workers per shift and 3 shifts per day. Direct labor supervision is $15 \%$ of direct labor. Plant maintenance labor and materials 
are each estimated as $2.264 \%$ of the total plant cost. Maintenance supervision is $20 \%$ of maintenance labor. Payroll overhead is $35 \%$ of the operating payro11. Operating supplies are estimated as $10 \%$ of plant maintenance (Kramer and Peters 1983). Lastly, indirects are estimated as $40 \%$ of the direct labor and maintenance. The total annual operating cost is $\$ 28,199,500$. 
TABLE B.4. Total Annual Operating Cost for a Washing/Calcining Facility for the Reprocessing of Hydrargillite

DIRECT COST :

Utilities:

Fossil Fue?

Water

$\$ 20,831,400$

32,500

Direct Labor:

Labor $15 / \mathrm{hr}$

Supervision (15\% of 1 abor)

657,600

98,600

756,200

P1ant Maintenance:

Labor (2.264\% of total plant cost)

Supervision (20\% of maintenance labor)

$1,616,200$

Materials (2.264\% of total plant cost)

323,200

Total

$1,616,200$

$3,555,600$

Payrol1 overhead, $35 \%$ of above payrol1

943,500

operating supplies, $10 \%$ of plant maintenance

355,600

$1,299,100$

TOTAL DIRECT

$26,474,800$

INDIRECT COST ( $40 \%$ of direct labor and maintenance)

$\underline{1,724,700}$

TUTAL ANNUAL OPERATING COST

$28,199,500$

TOTAL ANNUAL OPERATING COST, $\$ /$ ton $\cdot A T$

54.29

TOTAL ANNUAL OPERATING COST, \$/ton·alumina

28.20

TOTAL ANNUAL OPERATING COST, \$/ton-hydrargillite

16.50

TITIAL ANNUAL OPERATING COST, $\$$ /tonne $\cdot A T$

59.85

TJTAL ANNUAL OPERATING COST, $\$$ /tonne -alumina

31.08

TJTAL ANNUAL OPERATING COST, \$/tonne-hydrargilite

18.20 


\section{DISTRIBUTION}

No. of

Copies

\section{OFFSITE}

A. R. Landgrebe

U.S. Department of Energy

Forrestal Building, CE-32

1000 Independence Avenue, S.W.

washington, DC 20585

R. Eaton III

U.S. Department of Energy

Forrestal Building, CE-32

1000 Independence Avenue, S.W.

Washington, DC 20585

J. E. Quinn

U.S. Department of Energy

Forrestal Building, CE-32

1000 Independence Avenue, S.W.

Washington, DC 20585

P. Patil

U.S. Department of Energy

Office of Transportation Systems

Forrestal Building, CE-152

1000 Independence Avenue, S.W. Washington, DC 20585

J. W. Evans

Lawrence Berkeley Laboratory

Department of Material Science

University of California

1 Cyclotron Road, 90/3026

Berkeley, CA 94720

F. McLarnon

Lawrence Berkeley Laboratory

University of California

1 Cyclotron Road, 90/3026

Berkeley, CA 94720
No. of

Copies

E. J. Cairns

Lawrence Berkeley Laboratory

University of California

1 Cyclotron Road, 90/3026

Berkeley, CA 94720

J. McBreen

Brookhaven National Laboratory

DEE Building

Upton, NY 11973

K. Kinoshita

Lawrence Berkeley Laboratory

University of California

1 Cyclotron Road, 90/3026

Berkeley, CA 94720

P. N. Ross

Lawrence Berkeley Laboratory

University of California

l Cyclotron Road, 62/203

Berkeley, CA 94720

N. J. Magnani

Sandia National Laboratories

2520

P.0. Box 5800

Albuquerque, NM 87185

M. McMonigle

U.S. Department of Energy

Office of Industrial Programs

Forrestal Building/CE-142

1000 Independence Avenue, S.W. Washington, DC 20585

E. J. Rudd

ELTECH Systems Corporation

625 East Street

Fairport Harbor, $\mathrm{OH} 44077$ 
No. of

Copies

H. S. Alcazar

Pinnacle Research Institute 10432 North Tantau Avenue

Cupertino, CA 95014

J. Huff

Electronics Division

Los Alamos National Laboratory MS D429

P.0. Box 1663

Los ATamos, NM 87545

3. Dunning

General Motors Research

Laboratories

Electrochemistry Department

RCEL Building

Warren, MI 48090-9058

G. Henriksen

EG\&G Idaho

P.0. Box 1625

Idaho Falls, ID 83415

D. Zuckerbrod

Westinghouse Research \&

Development Center

1310 Beulah Road

Pittsburgh, PA 15235

R. W. Fenn

ELTECH Systems Corporation

625 East Street

Fairport Harbor, $\mathrm{OH} 44077$

M. Nicksa

ELTECH Systems Corporation

625 East Street

Fairport Harbor, $\mathrm{OH} 44077$

C. J. McMinn

Reynolds Aluminum Company

Reduction Research Division

P.0. Box 1200

Sheffieid, AL 35660
No. of

Copies

N. Richards

Reynolds Aluminum Company

Reduction Research Division

P.D. Box 1200

Sheffie]d, AL 35660

G. Tarcy

ALCOA Labs

P.0. Box 772

New Kensington, PA 15068

A. Maimoni

Lawrence Livermore National Laboratory

Livermore, CA 94550

J. F. Cooper

Lawrence Livermore National

Laboratory

Livermore, CA 94550

T. Gi]liam

ELTECH Systems Corporation

625 East Street

Fairport Harbor, $\mathrm{OH} \mathbf{4 4 0 7 7}$

J. W. Hurwitch

Energetics, Inc.

9210 Route 108

Columbia, MD 21045

L. Frank

ELTECH Systems Corporation

625 East Street

Fairport Harbor, $\mathrm{OH} \quad 44077$

J. E. Clifford

Battelle Columbus Laboratorjes

$505 \mathrm{King}$ Avenue

Columbus, $\mathrm{OH} 43201$

E. Torrie

Batte? le Columbus Laboratories 505 King Avenue

Columbus, $\mathrm{OH} 43201$ 
No. of

Copie로

2. M. Associates

2.0. Box 30

Jooperstown, NY 13326

S. W. Eckroad

Bechtel Group

50 Beale Street

San Francisco, CA 94119

R. Fedora

¿\&D Battery Division

3043 Walton Road

PJymouth Meeting, PA 19462

E. S. Carr

Eagle-Picher Industries, Inc.

P.0. Box 130

Seneca, MO 64865

P. Symons

Electrochemical Engineering Consultants, Inc. 1295 Kelly Park Circle

Morgan $\mathrm{HjI1}$, CA 95037

$R$. Weaver

Electric Power Research

Institute

P.0. Box 10412

Palo Alto, CA 94303

L. O'Connell

Electric Power Research

Institute

P.0. Box 10412

Palo Alto, CA 94303

\section{A. Leo}

Energy Research Corporation

Three Great Pasture Road

Danbury, CT 06810

V. M. Haisall

Johnson Controls

P.0. Box 591

Milwaukee, WI 53201
No. of

Copies

\author{
W. P. Sholette \\ Exide Management and Technology \\ 19 West College Avenue \\ P.0. Box 336 \\ Yardlem, PA 19067 \\ J. Szymborski \\ GNB Batteries, Inc. \\ 2050 Cabot Blvd. West \\ Langhorne, PA 19047 \\ B. Burrows \\ Gould Laboratories \\ 40 Gould Center \\ Rolling Meadows, IL 60008 \\ E. Buzzelli \\ Westinghouse R\&D Center \\ 1310 Beulah Road \\ Pittsburgh, PA 15235 \\ J. Dunlop \\ Comsat Laboratories \\ 22300 Comsat Drive \\ Clarksburg, MD 20871 \\ B. Auxer \\ Beta Power, Inc. \\ 489 Devon Park Drive \\ Suite 315 \\ Wayne, PA 19087 \\ D. D. MacDonald \\ SRI Internationa? \\ 333 Ravenswood Avenue \\ Men 10 Park, CA 94025 \\ F. Solomon \\ Electromedia Corporation \\ 111 Cedar Lane \\ Englewood, NJ 07631 \\ M. A. Dzieciuch \\ Ford Motor Company \\ Vehicle Systems Department \\ P.0. Box 2053 \\ Dearborn, MI 48121-2053
}


No. of

Copies

R. Schainker

Electric Power Research Institute

P.0. Box 10412

Paio Alto, CA 94303

B. Askew

Energy Management \& Utilization Division

Electric Power Research Institute

P.0. Box 10412

Palo Alto, CA 94303

T. Mulcahey

Argonne National Laboratory

9700 South Cass Avenue

Argonne, IL 60439

J. Stoval1

Martin Marietta Energy

Systems, Inc.

P.0. Box X

Oak Ridge, TN 37831

R. K. Sen

3808 Veazey St., N.W.

Washington, DC 20016

3. A. Consiglio

Solva-Tec Associates

277 High Street

Topsfield, MA 01983

V. Babbitt

Battery Power Systems, Inc.

P.0. Box 98521

Seattle, WA 98188
No. of

Copies

R. Diegle

Sandia National Laboratories 2520

P.0. Box 5800

Albuquerque, NM 87185-5800

R. A. Rand

Alcoa Aluminum Company

P.0. Box 300

Bauxite, AR 72011

12 DOE/Office of Scientific and Technica] Information

\section{ONSITE}

DOE Richland Operations office

D. R. Segna

40 Pacific Northwest Laboratory

L. L. Fassbender

C. H. Imhoff

R. C. Adams

D. A. Seaver

J. R. Divine

D. R. Brown (10)

K. K. Humphreys (15)

C. L. Bruneau

S. C. Marchman

J. A. Dirks

G. L. McVay

Publishing Coordination (1)

Technica] Report files (5) 